\title{
Perinatal COVID-19: review of current evidence and practical approach towards prevention and management
}

\author{
Venkateshwarlu Vardhelli ${ }^{1}$ - Aakash Pandita ${ }^{2}$ (D) Anish Pillai $^{3} \cdot$ Susanta Kumar Badatya ${ }^{4}$ \\ Received: 31 July 2020 / Revised: 28 October 2020 / Accepted: 30 October 2020 / Published online: 12 November 2020 \\ (C) Springer-Verlag GmbH Germany, part of Springer Nature 2020
}

\begin{abstract}
The clinical spectrum of the perinatal COVID-19 and prospective data on neonatal outcomes remains largely unexplored. Most of the existing literature is in the form of case series or single-centre experience. In this review, we aim to summarize available literature on the clinical spectrum of COVID-19 in neonates and mothers and suggest a practical approach towards management of clinical scenarios. This review explores the clinical characteristics and outcomes of COVID-19 in neonates born to mothers who were detected with the virus during the pregnancy. We conducted a comprehensive search of PubMed, Google Scholar and Cochrane Database of Systematic Review between November 2019 and June 2020 and screened articles related to perinatal COVID-19. This review included 786 mothers, among which 64\% (504) were delivered by caesarian section. There were 3 still births and 107 (14\%) were delivered preterm. Out of 793 neonates born, 629 neonates (79\%) were tested after birth. The commonest symptom in neonates was respiratory distress. Respiratory support was needed in 60 neonates (7.6\%), with 14 babies needing mechanical ventilation (1.8\%), 25 needing non-invasive ventilation and 21 needing nasal oxygen. Only 35 of the 629 tested neonates (5.5\%) were positive for COVID-19. Of the 35 positive neonates, 14 (40\%) were symptomatic. The COVID-19 seems to have favourable neonatal outcomes. Majority of neonates are asymptomatic. Respiratory distress is the most common manifestation.
\end{abstract}

\section{What is known:}

- COVID-19 affects all ages.

- Neonatal disease is usually mild.

What is new:

- Vertical transmission is a possible route of infection in neonates.

- Breast milk and skin-to-skin contact are safe in COVID-19-infected mothers if performed with appropriate use of precautions such as hand and breast hygiene and masking.

Keywords COVID-19 $\cdot$ Perinatal COVID $\cdot$ SARS-COV-2 $\cdot$ Neonatal Sepsis

\section{Communicated by Daniele De Luca}

\section{Aakash Pandita}

aakash.pandita@gmail.com

Venkateshwarlu Vardhelli

venkat959@gmail.com

Anish Pillai

anishgp1@yahoo.co.in

Susanta Kumar Badatya

skb48072@gmail.com
Fernandez Hospital, Hyderabad, Telangana, India

2 Department of Neonatology, SGPGIMS, Lucknow, UP, India

3 Surya Children's Medicare, Mumbai, India

4 Department of Pediatrics, Apollo Cradle, Moti Nagar, New Delhi, India 


\section{Abbreviations \\ ACE-2 Angiotensin-converting enzyme 2 \\ HCoVs Human coronaviruses \\ SARS-CoV Severe acute respiratory distress syndrome coronavirus \\ ILI Influenza like illness \\ MERS CoV Middle East respiratory syndrome-related coronavirus \\ PUI Person under investigation}

\section{Introduction}

Coronaviruses are positive sense single strand RNA viruses of zoonotic origin surrounded by an envelope. The Coronaviridae family has Orthocoronavirinae subfamily which is further divided into four genera, namely, Alpha, Beta, Gamma, and Delta coronavirus [1,2]. So far, seven human coronaviruses (HCoVs) have been identified, all of which fall within the Alpha and Beta coronavirus genera. The severe acute respiratory distress syndrome coronavirus (SARS-CoV), Middle East respiratory syndrome-related coronavirus (MERS $\mathrm{CoV}$ ) and novel severe acute respiratory syndrome coronavirus-2 (SARS-CoV-2) belong to the genus Beta coronavirus [2-5].

In early December 2019, an outbreak of respiratory illness of unknown origin was reported in Wuhan, Hubei Province, China, which was later isolated and reported as SARS-CoV-2 virus $[6,7]$. Since the beginning of this epidemic, SARSCoV-2 has now spread to all continents and was declared as pandemic by WHO on March 11, 2020 (https://www.who.int/ docs/default-source/coronaviruse/situation-reports/ 20200311-sitrep-51-covid-19.pdf?sfvrsn=1ba62e57_10) [8-11]. SARS-CoV-2 infection has also been reported in pregnant women and neonates, but the data is scattered and limited [12].

\section{Methodology}

We conducted a comprehensive review of literature describing perinatal SARS-CoV-2 infection which included articles published between November 2019 and June 2020. To identify relevant articles, we systematically searched PubMed, Google Scholar and Cochrane Database of Systematic Review. For searching PubMed, we combined the population terms ("Infant"[Mesh] OR "premature birth"[MeSH Terms] OR newborn OR neonat* OR perinat*) and the outcome terms ("COVID-19" [Supplementary Concept] OR "SARS-CoV" OR "coronavirus" OR "COVID-19" OR "SARS-CoV-2" OR "novel coronavirus" OR "neonatal covid" OR "2019nCOV"). The initial search yielded 873 articles, of which 824 were in English. We found 6 meta-analyses, of which 3 were related to perinatal COVID-19. No randomized control trials were found. After excluding duplicates, the rest of the articles comprising of observational studies (single and multicentre) and case reports were screened by 2 researchers independently. Similarly, the Cochrane Database of Systematic Review and Google Scholar were searched. All relevant prospective/retrospective studies (including case reports) and review articles were included. Further, a rapid review was conducted to include more recent articles up to August 2020. Guidelines and recommendations of relevant national and international organizations were also reviewed. In this article, we discuss important aspects of perinatal-neonatal COVID-19 infection, systematically summarize current evidence (updated to June 2020) and propose a practical approach towards its management and prevention in neonates.

\section{Transmission of COVID-19}

The SARS-CoV-2 enters the host cell by attaching to the SARS-coronavirus receptor, angiotensin-converting enzyme 2 (ACE-2). The entry is facilitated by the spike (S) protein. ACE-2 is a surface molecule expressed in alveolar type 2 cells of lung, oesophageal upper epithelial cells and absorptive enterocytes from ileum and colon [13]. The novel SARSCoV-2 transmits between humans through the respiratory droplets and aerosols from coughing and sneezing usually up to $6 \mathrm{ft}$. It can also be transmitted through direct or indirect contact with mucous membranes of the eyes, mouth or nose [14]. Possibility of infection through gastrointestinal tract has also been reported in a study by invasion of ACE- 2 expressing enterocytes [15]. According to the initial available literature, the risk of vertical transmission is $5-30 \%$ but may be underreported due to lack of early diagnosis. ACE2 receptors and TMPRSS 2 molecules are highly expressed in placenta and the expression peaks at term and the virus often invade the placenta and rarely cause miscarriage [16-19]. From two different case series, 4 infants had positive nasopharyngeal SARS-CoV-19 RT-PCR within 2 days of life, but cord blood, amniotic fluid and cord blood samples were negative in these infants $[20,21]$. Serological testing with SARS-CoV-2specific IgM and IgG showed positive IgM in serum of 3 out of 7 newborns in two different studies with negative nasopharyngeal swab and serum RT-PCR in the same infants $[22,23]$. Serum IgM can give both false positive and false negative results depending on the technique used. It is very difficult to differentiate early postnatal transmission/ colonization versus vertical transmission in neonates. There are cases of neonatal detection for SARS-CoV-2 within the first $24 \mathrm{~h}$ of life. An infant born to a 41-year-old pregnant woman with severe COVID-19 infection requiring mechanical ventilation tested positive at $16 \mathrm{~h}$ age. The patient underwent a caesarean delivery, and the neonate was isolated 
immediately without delayed cord clamping or skin-to-skin contact. The serology tests IgM and IgG for SARS-CoV-2 were negative [24]. Another recent case by Kirstman et al. reports a term male infant born to a 40-year-old COVID-19positive mother by caesarian section. The infant did not require resuscitation at birth but was admitted to NICU at $37 \mathrm{~h}$ for temperature instability, hypoglycaemia and feeding difficulty. The infant had positive RT-PCR from nasopharyngeal swab on day of birth, day 2 and day 7. Also, this is the first report where samples of placenta, maternal vaginal swab and breast milk were positive for the virus [25]. Another study tested multiple breast milk samples in two COVID-19positive mothers. Authors reported positive RT-PCR in one mother on days 10, 12 and 13. Further breast milk samples repeated later were negative. [26] In a case report of preterm infant born to mother with COVID-19, infant had fever after birth and was treated with intravenous antibiotics. Maternal vaginal secretions, umbilical cord blood, neonatal nasal and throat swabs at birth were negative for SARS-CoV-2. But amniotic fluid sample was positive. The second nasal swab test at $24 \mathrm{~h}$ was positive for SARS-CoV-2. Third and fourth neonate's PCR test was positive 1 week later. In this case, the neonate was separated from mother at birth and was fed with formula [27]. These findings raise the uncertainty regarding transmission of SARS-CoV-2 by placenta and human milk and highlight the importance of measures to prevent horizontal transmission. Previous case series have not detected COVID-19 virus in breast milk or placenta [28-31]. Recently there have been few case reports suggestive of secretion of coronavirus in breast milk [32]. However, in a case series of 18 mothers, data suggests that the presence of SARSCoV-2 RNA in breast milk does not represent replicationcompetent virus and that breast milk may be safe for the infant. Furthermore, pasteurization by Holders technique has shown to completely destroy the viral RNA present in the breast milk [33]. Neonates may also acquire infection postnatally from close contact with other COVID-19-positive people such as healthcare workers and family members.

\section{Clinical presentation}

The mean incubation period of COVID-19 is 5.2 days (95\% CI: 4.1-7 days) with over $90 \%$ infected individuals developing symptoms within the initial 10 days. Based on these findings, 14-day monitoring period is advised after contact with a COVID-19-confirmed case. The reproduction number (R0), defined as average number of secondary infections caused by one infected person in a naïve population, ranges from 1.4 to 6.49 with the mean of 3.28 , which is higher compared to H1N1 influenza (R0 of 1.2-1.6) and SARS-CoV (R0 of 25) [34-36].
According to the published literature, the clinical characteristics of pregnant women with COVID-19 are similar to nonpregnant COVID-19 adult patients [36-44]. In our review that included 786 mothers, we found that $64 \%$ (504) delivered by caesarian section. There were 3 still births, and 107 (14\%) were delivered preterm. The gestation was not specified in 33\% of cases, and the rest were term neonates. A recently conducted systematic review and meta-analysis on outcomes of coronavirus spectrum infections in pregnancy included 19 studies with 79 women affected with SARS, MERS and SARS-CoV-2 infections. The authors reported miscarriage in $39.1 \%$, preterm birth ( $<37$ weeks) in $24.3 \%$, premature pre-labour rupture of membranes (pPROM) in $20.7 \%$, preeclampsia in $16 \%$ and foetal growth restriction in $11.7 \%$ of COVID-19 mothers [29]. On subgroup analysis consisting of 41 pregnancies with COVID19 (SARS-CoV-2 infections), the most common adverse pregnancy outcome was preterm birth. It was reported in $56 \%$ of patients, of which $15 \%$ delivered before 34 weeks. The perinatal mortality was $7 \%$, including one still birth and one neonatal death [29]. Furthermore, pPROM was observed in $18.8 \%$ of patients [29]. However, it is important to emphasize these data reflect small numbers in early COVID-19 era, and the perinatal issues may not be directly related to maternal or neonatal infection with coronavirus.

The transmission and symptom profile of COVID-19 in neonates are described in Fig. 1. As per our compiled data, out of 793 neonates born, 629 neonates (79\%) were tested after birth. The commonest symptom in this group was respiratory distress. Respiratory support was needed in 60 neonates, with 14 babies needing mechanical ventilation, 25 needing non-invasive ventilation and 21 needing nasal oxygen. The respiratory symptoms are more likely related to prematurity, transient tachypnoea, and respiratory distress syndrome rather than COVID-19 pneumonia. Only 35 of the 629 tested neonates (5.5\%) were positive for COVID-19. However, it is difficult to rule out false negative cases, as the timing and protocol for testing was variable and the optimal protocol is currently unclear. Of the 35 positive neonates, 14 (40\%) were symptomatic. The commonly described symptoms were respiratory (tachypnoea, respiratory distress, cough), gastrointestinal (diarrhoea, vomiting, feed intolerance), lethargy and temperature instability. It is also difficult to assume if these symptoms are attributable to COVID-19 disease as few infants who tested negative also developed symptoms. [30] The potential severity of SARS-CoV-2 late onset sepsis has been discussed in the case report by Munoz et al. which describes manifestation of hypotension, need of mechanical ventilation with high settings and occurrence of pneumothorax [45]. Although the extent of disease severity is difficult to describe given the limited literature, majority of neonates have had mild disease. The available case reports and case series on neonates born to COVID-19 pregnant women are summarized in Table 1. 

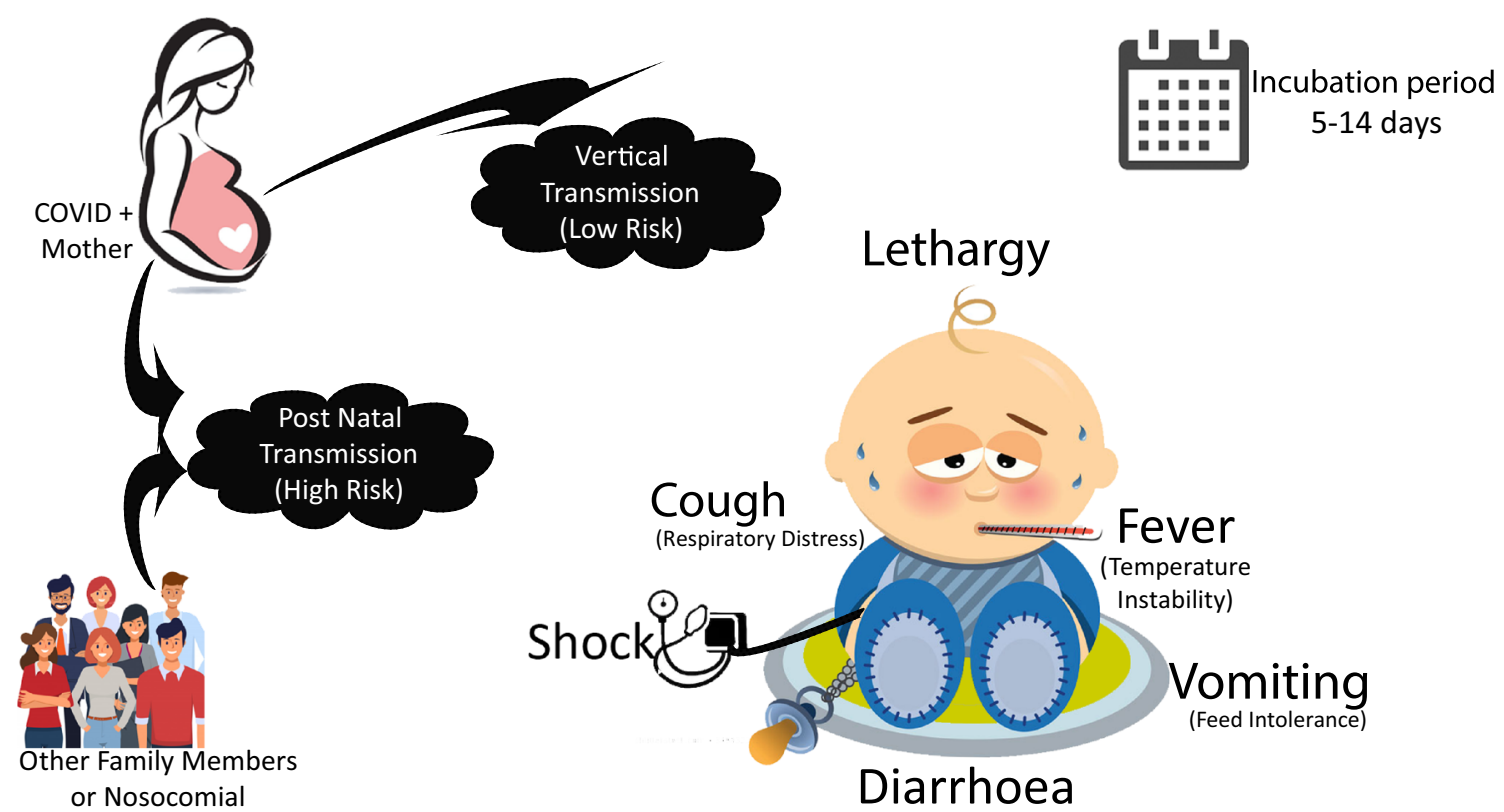

Nasopharyngeal Rectal Swabs for RT-PCR SARS COV-2

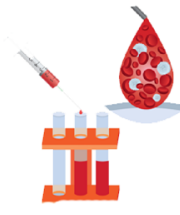

Blood investigations Leucocystosis with Lymphopenia and Thrombocytopenia. Raised CPK MB. Abnormal LFT

Fig. 1 Common neonatal symptoms of COVID-19

\section{Laboratory diagnosis}

Detection of viral nucleic acid by reverse transcriptase polymerase chain reaction (RT-PCR) is the current gold standard and confirmatory test for COVID-19 [46]. The sensitivity of RT-PCR depends on the precise RT-PCR assay, the type of specimen obtained, the quality of specimen and the duration of the illness at the time of testing. RT-PCR may be false negative in low viral load states like very early or late phase of disease [47]. Nasopharyngeal swab and oropharyngeal swab are recommended for screening or diagnosis of early infection (https://www.aappublications.org/news/2020/07/ 22 /newbornguidance 072220 ). In a study on the sensitivity of RT-PCR for various specimens, positivity rates were $93 \%$ for broncho-alveolar lavage, $72 \%$ for sputum, $63 \%$ for nasal swab, $46 \%$ for bronchoscopic brush biopsy, $32 \%$ for pharyngeal swabs, $29 \%$ for faeces, $1 \%$ for blood and $0 \%$ for urine specimens. Lower respiratory tract specimens have higher positive rates probably due to higher viral loads $[17,47,48]$ (https:// www.aappublications.org/news/2020/07/22/ newbornguidance072220). American Academy of Paediatrics (AAP) recommends testing with molecular assay on swabs of nasopharynx and throat (oropharynx) [one single swab to sample throat first and then the nasopharynx], initially at $24 \mathrm{~h}$ of age and repeat testing at $48 \mathrm{~h}$ of age. In mechanically ventilated neonates, tracheal aspirate should be tested. In the neonates with initial positive PCR test, follow-up testing with 48-72-h interval should be done until 2 consecutive negative tests (https://www.aappublications.org/news/2020/07/22/ newbornguidance072220). The Canadian Paediatric Society recommends testing within $2 \mathrm{~h}$ of life after cleansing the face to reduce colonization. For positive tests, repeat testing after $24-48 \mathrm{~h}$ is recommended. Optimal precautions should be ensured during sample collection and processing to avoid risk of exposure to virus due to aerosol transmission (https://www. cps.ca/en/documents/position/nicu-care-for-infants-born-tomothers-with-suspected-or-proven-covid-19).

Serological tests are less likely to be reactive in the first several days of infection so are less useful in diagnosis of acute infection. Sensitivity of ELISA is $87 \%$ compared to $82 \%$ by immunochromatographic card test [49]. Similarities in genetic sequence with other viruses cause cross-reactivity and high false positive rates for serological tests. In a recent study, the positive detection rate was significantly increased (98.6\%) when IgM ELISA assay was combined with PCR for each patient compared to qPCR test alone (51.9\%) [50] (Fig. 2). Serological surveys can aid in investigation of an ongoing outbreak and in retrospective assessment of the attack rate or extent of an outbreak (https://www.who.int/newsroom/commentaries/detail/advice-on-the-use-of-point-ofcare-immunodiagnostic-tests-for-covid-19). A recent report on placental pathology in 16 women with SARS-CoV-2 infection showed features of decidual arteriopathy and maternal vascular malperfusion [51]. These findings are also seen in 


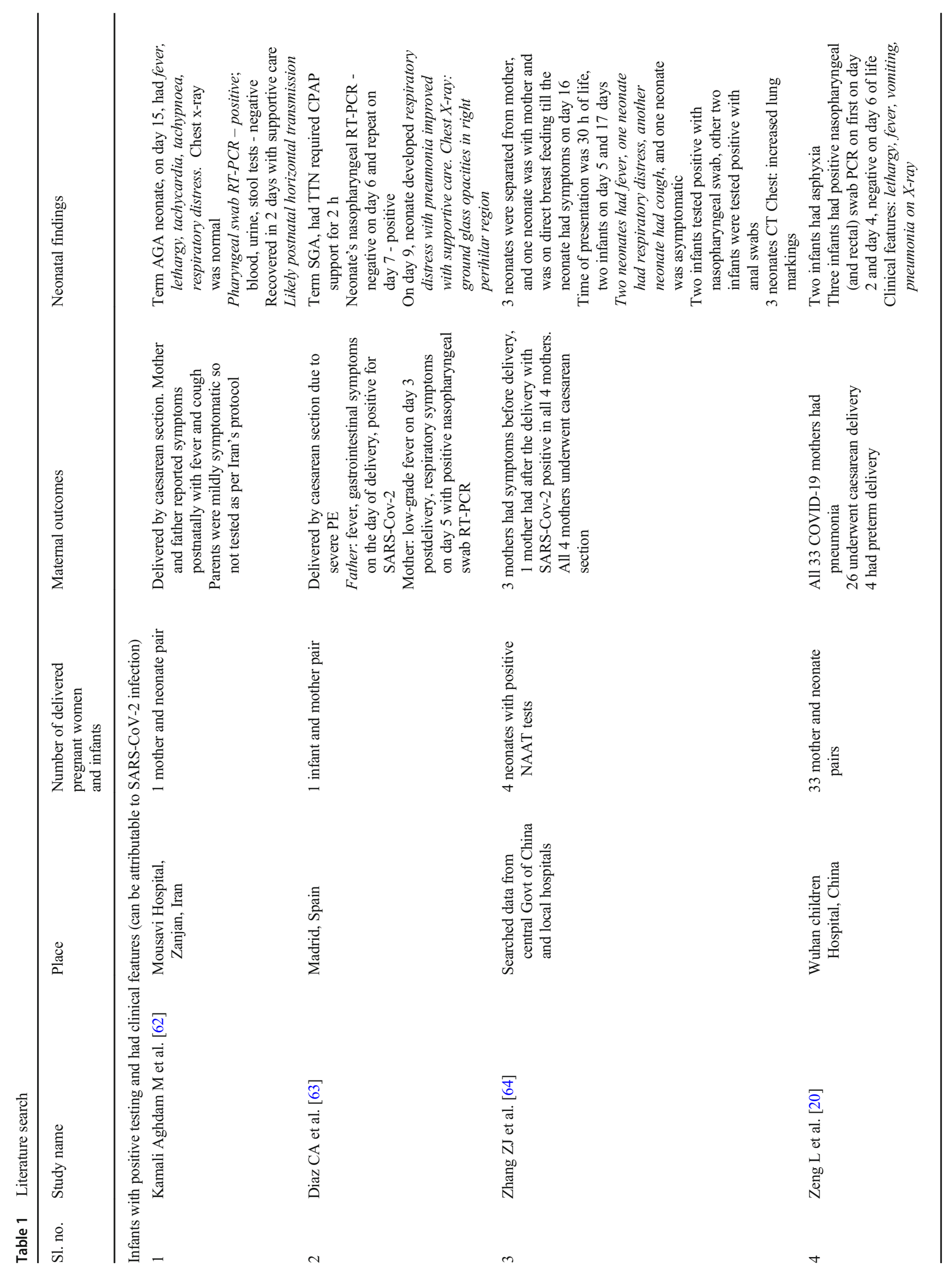




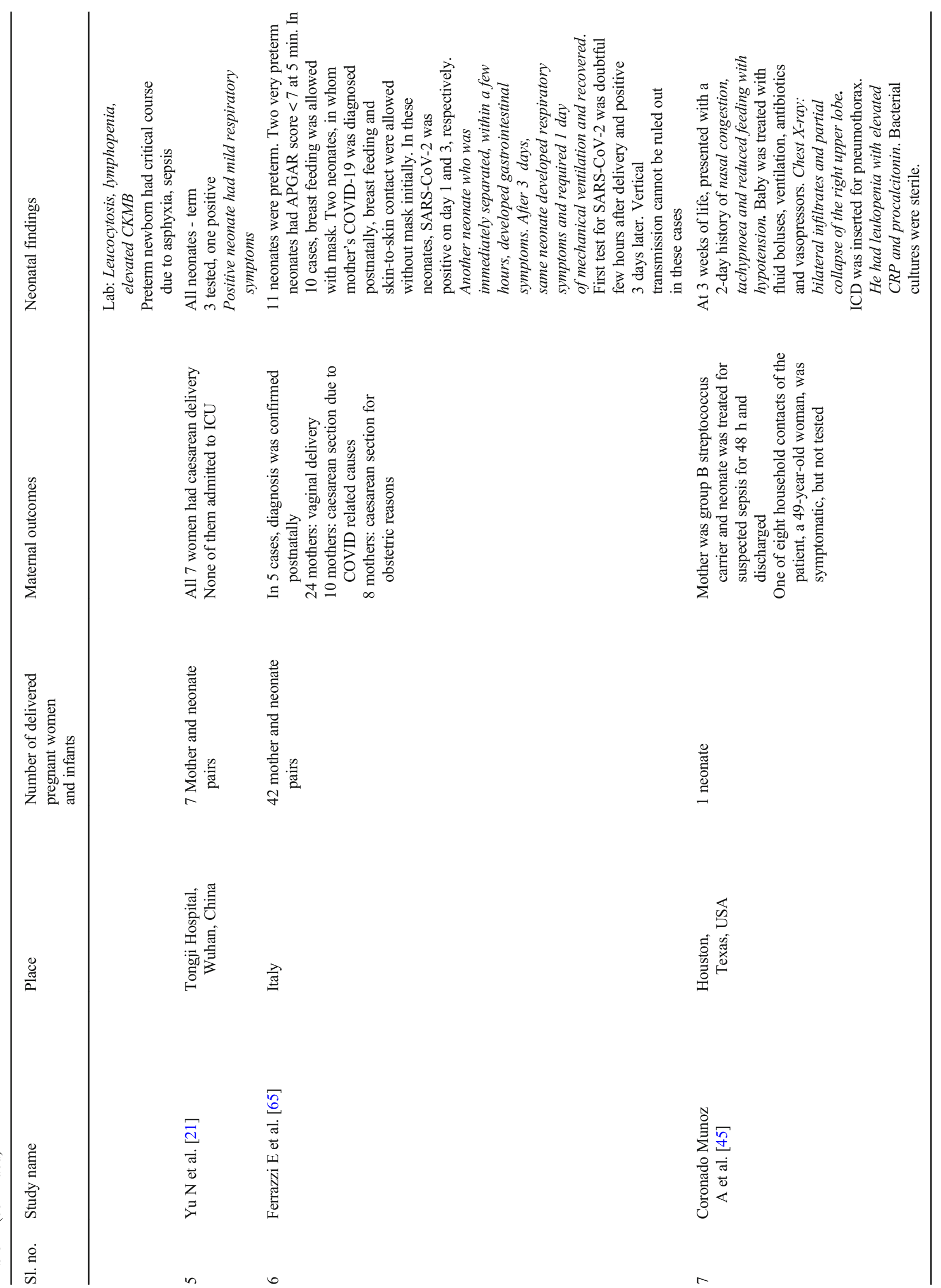




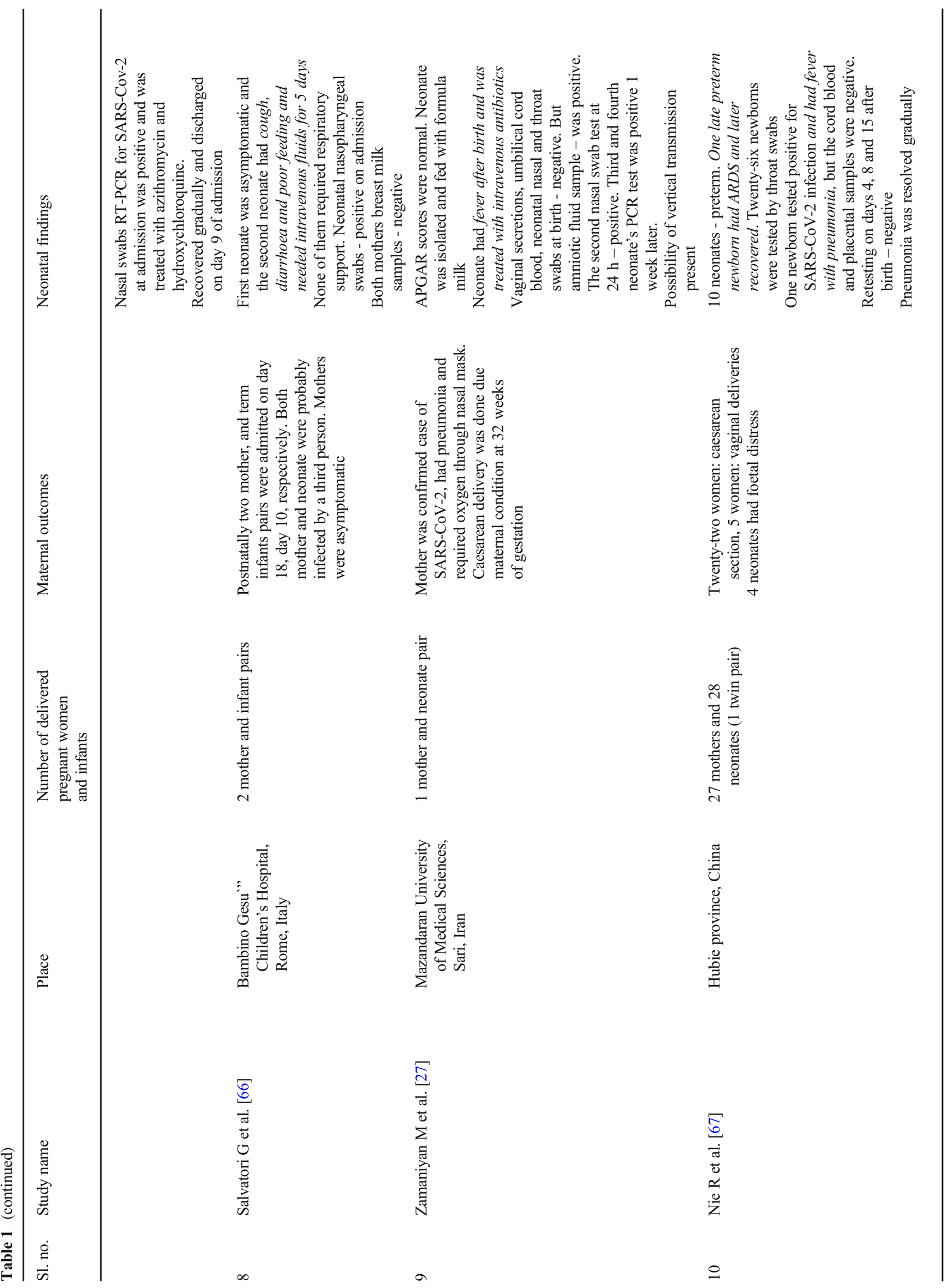




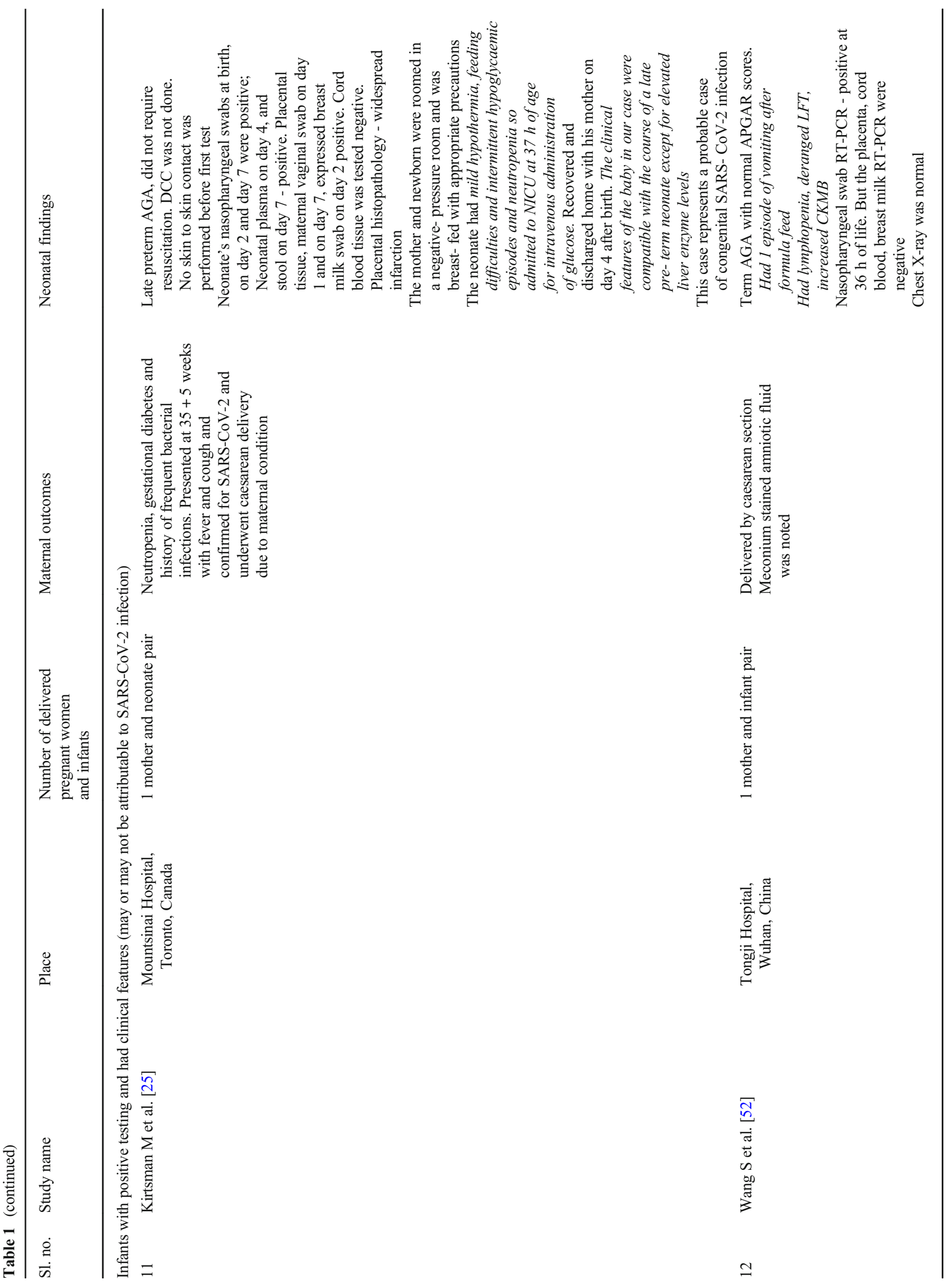




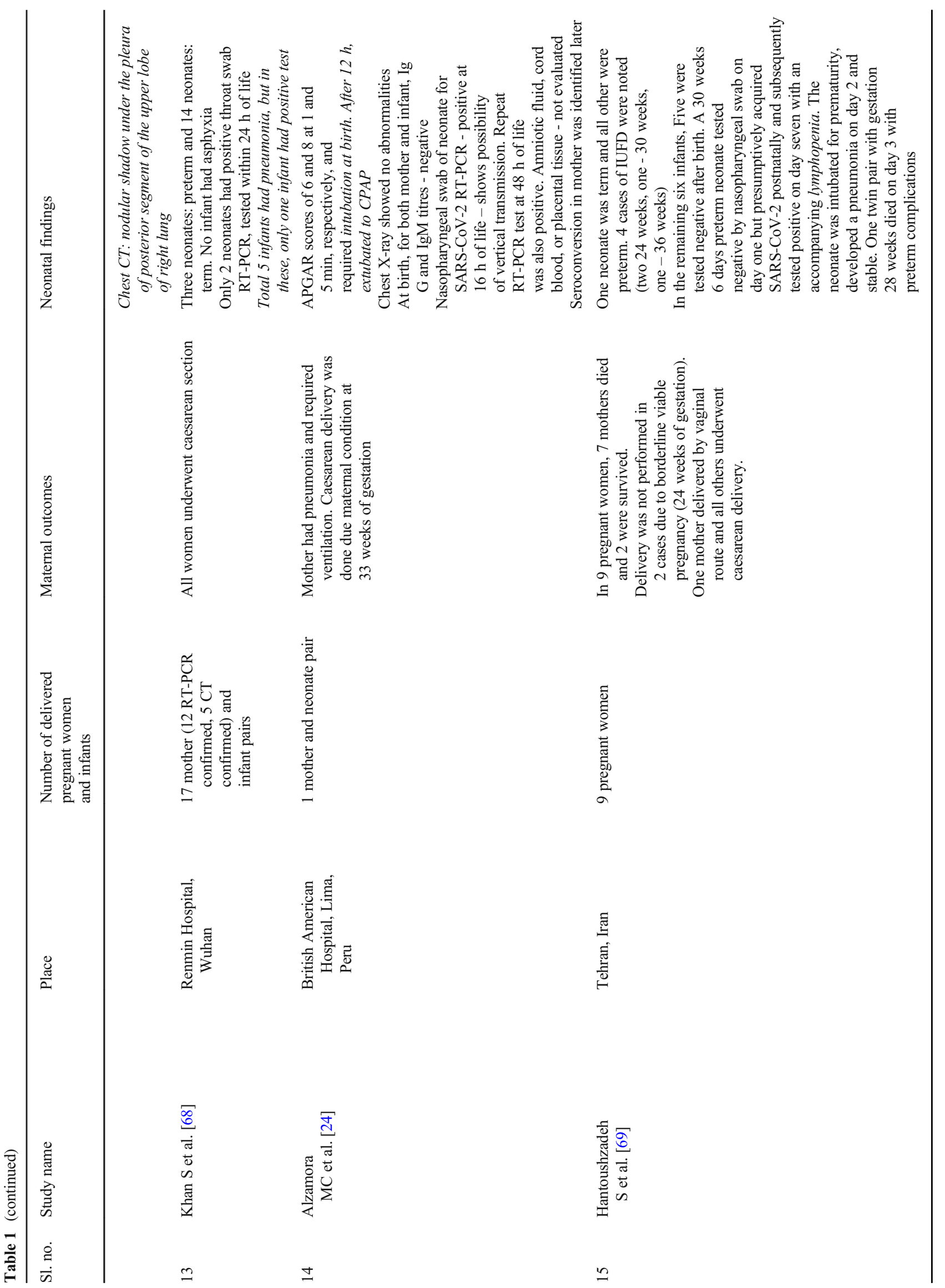




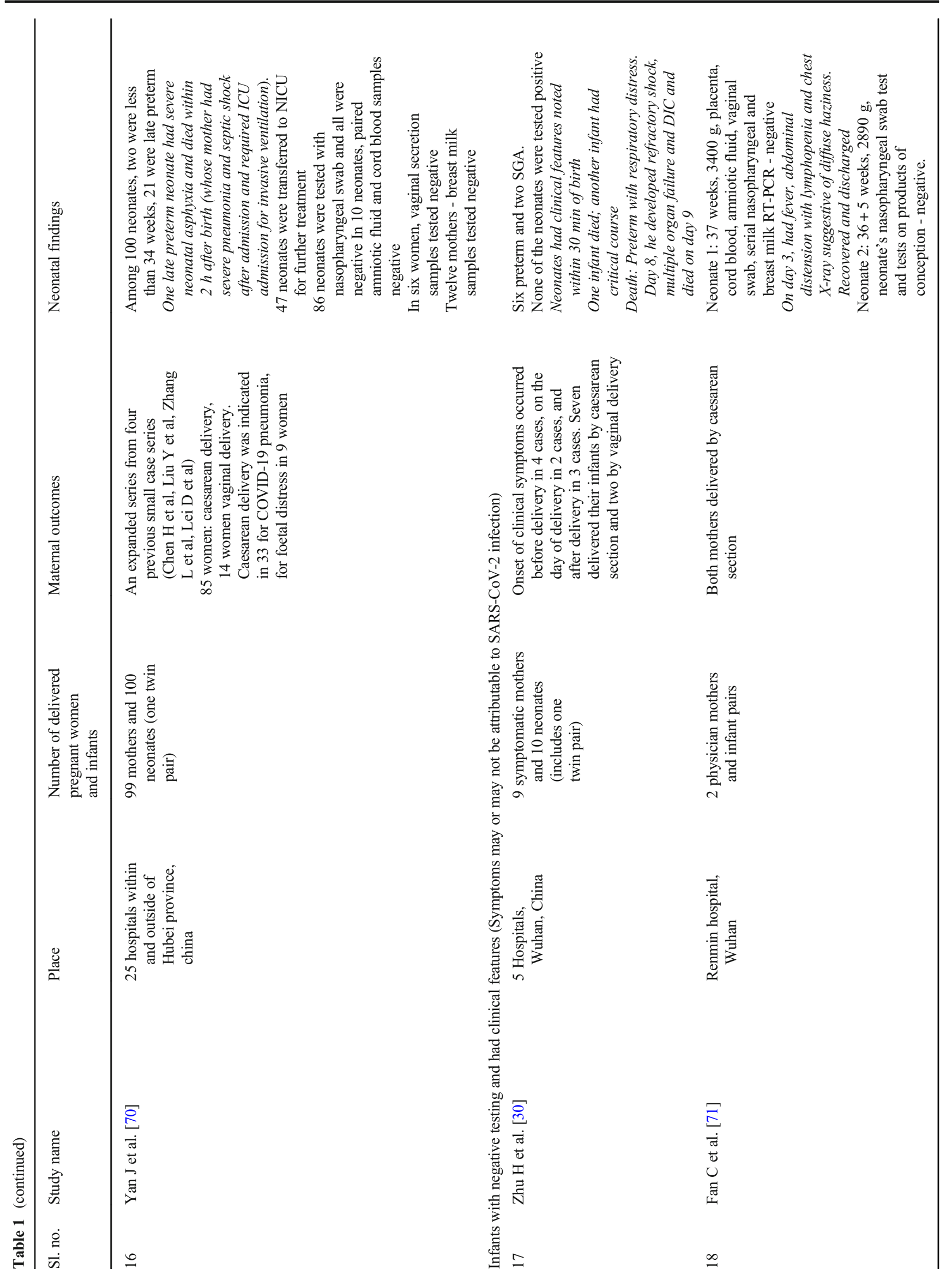




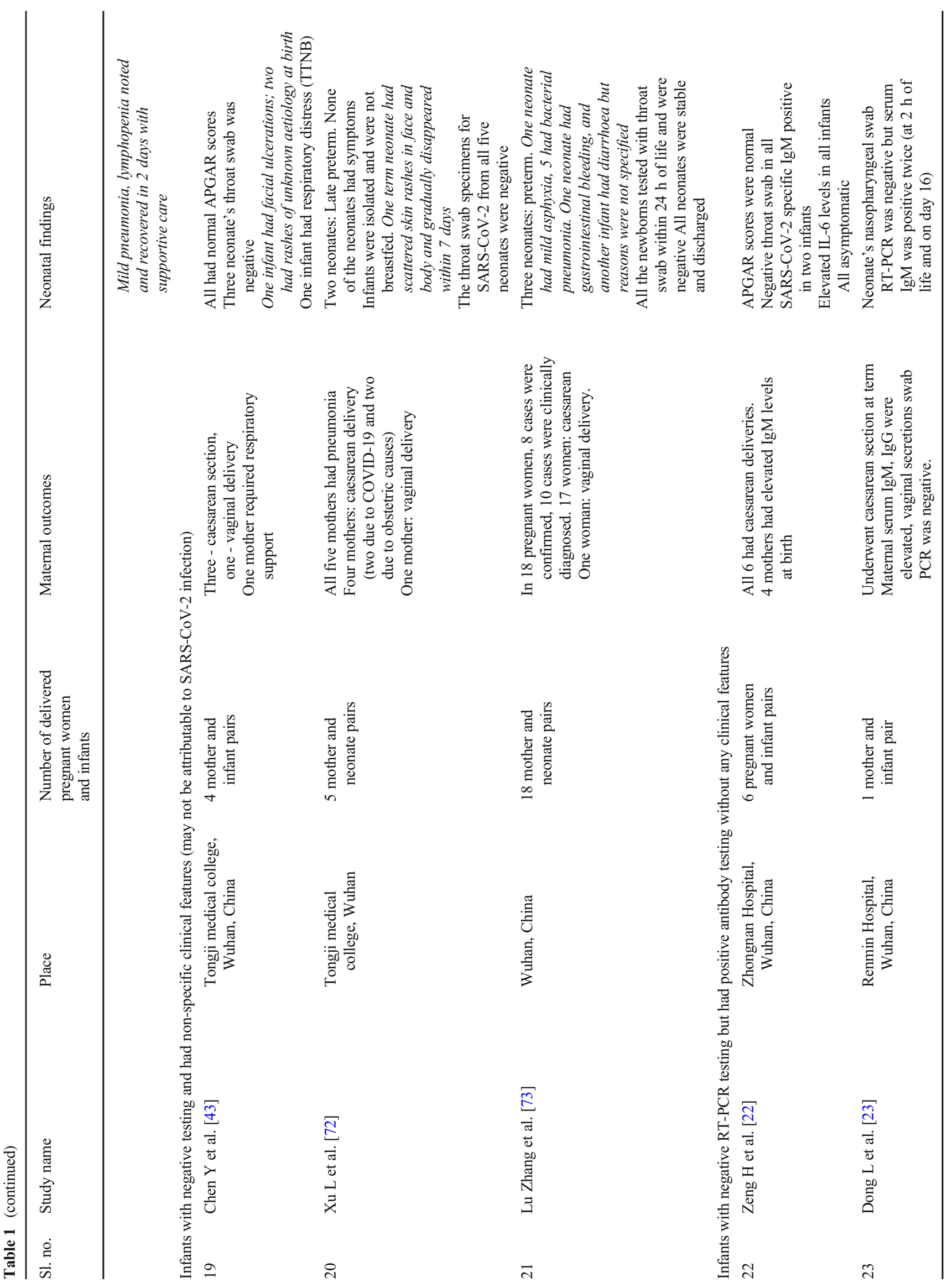




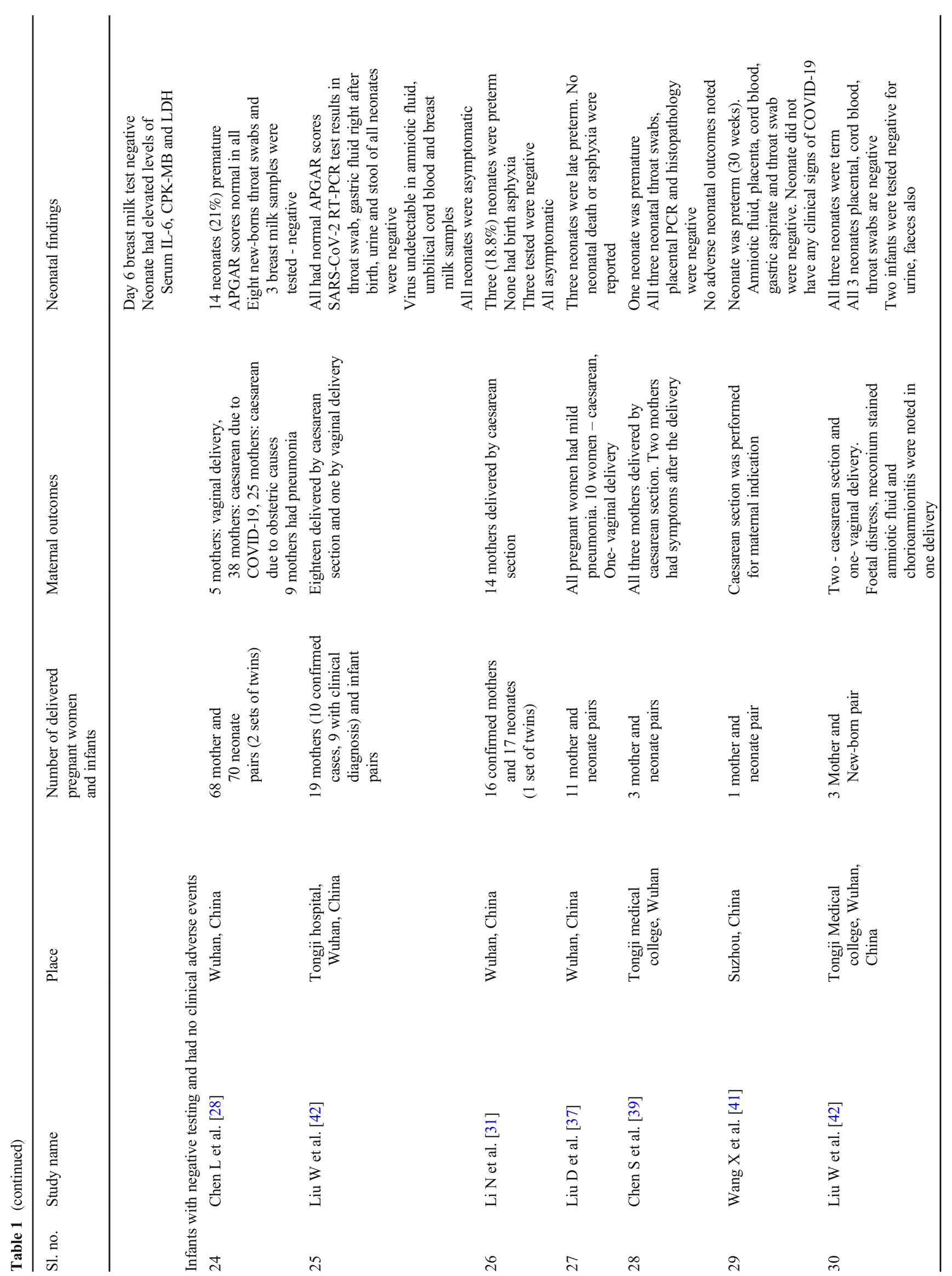




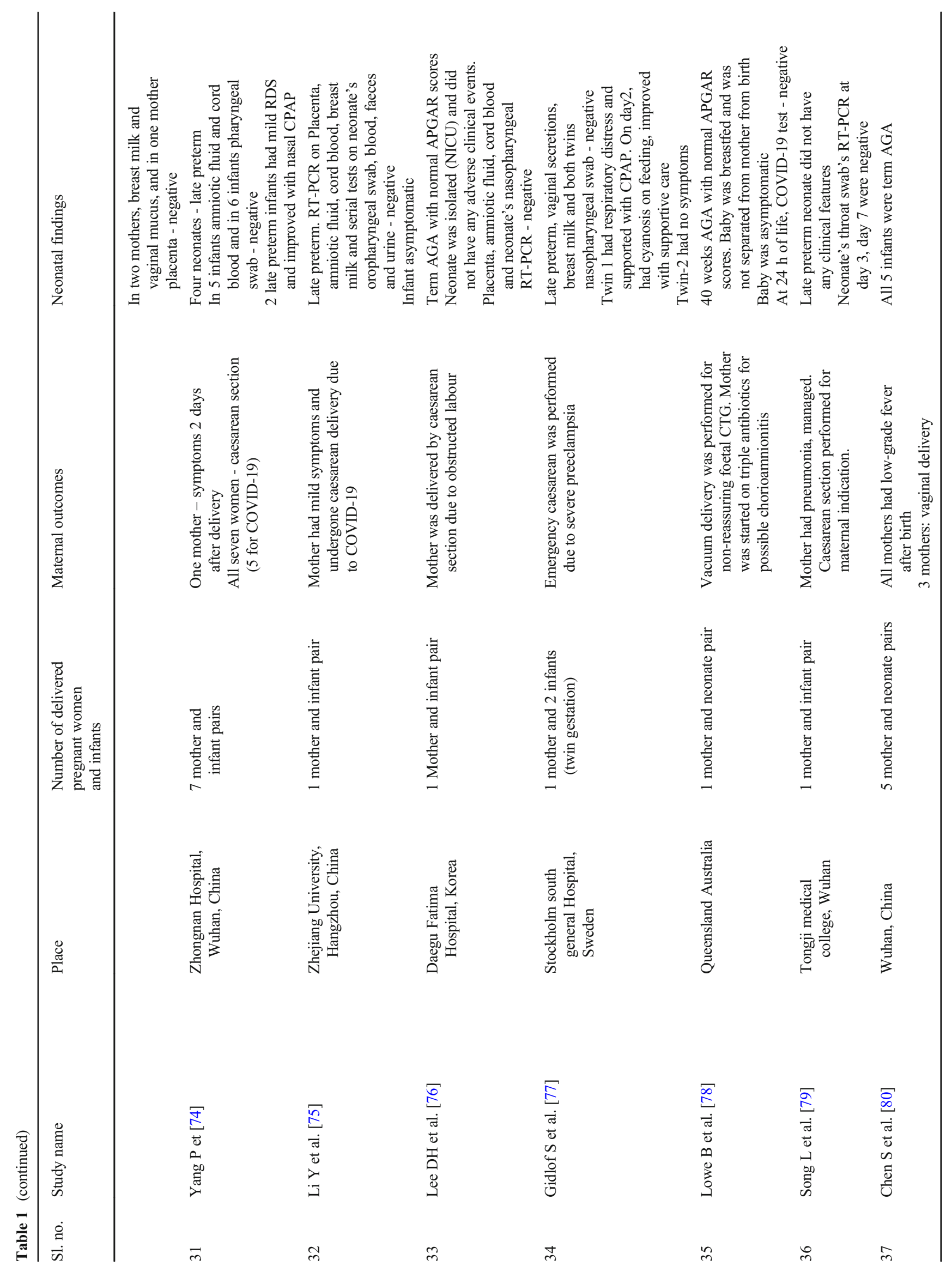




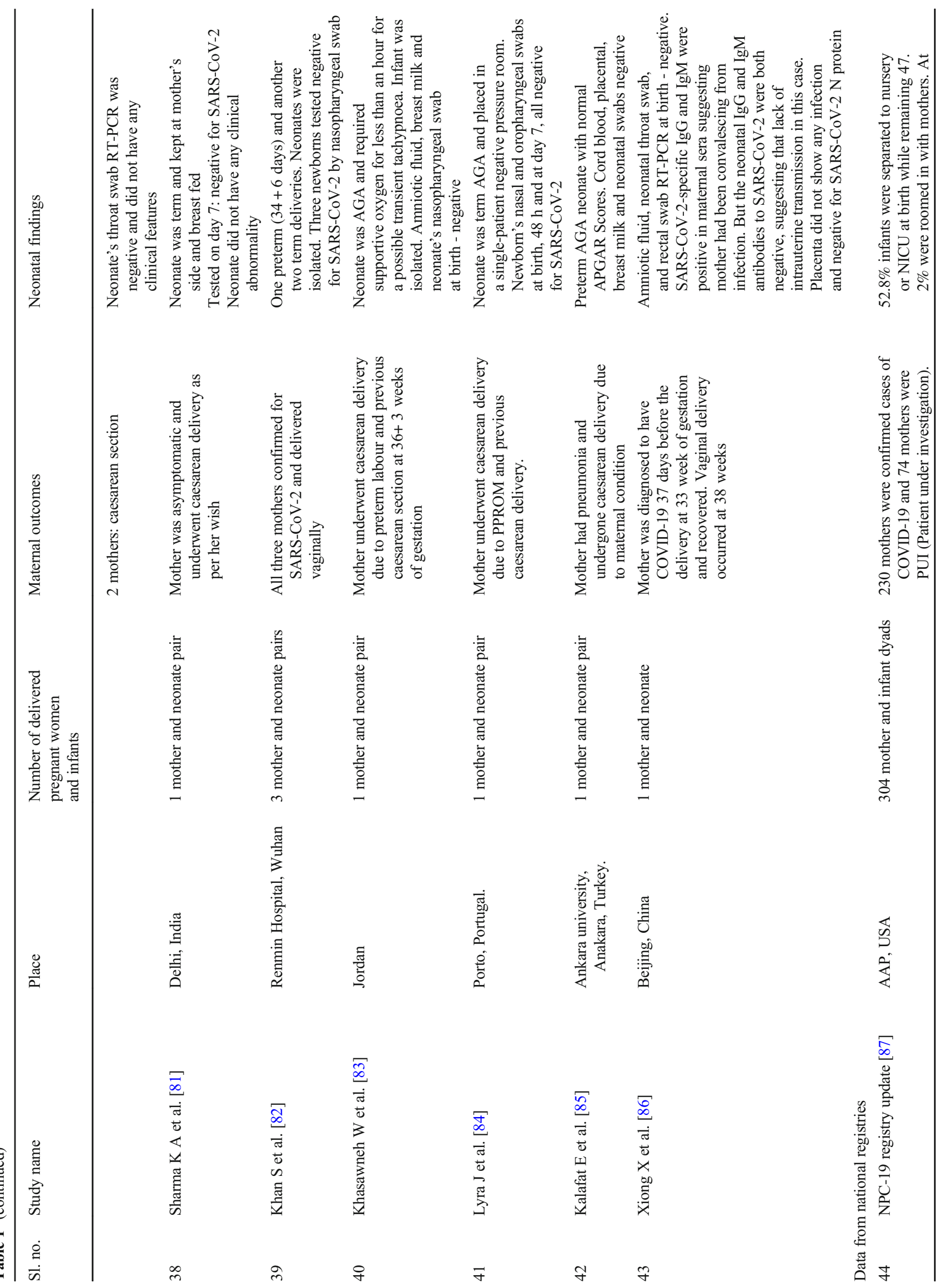




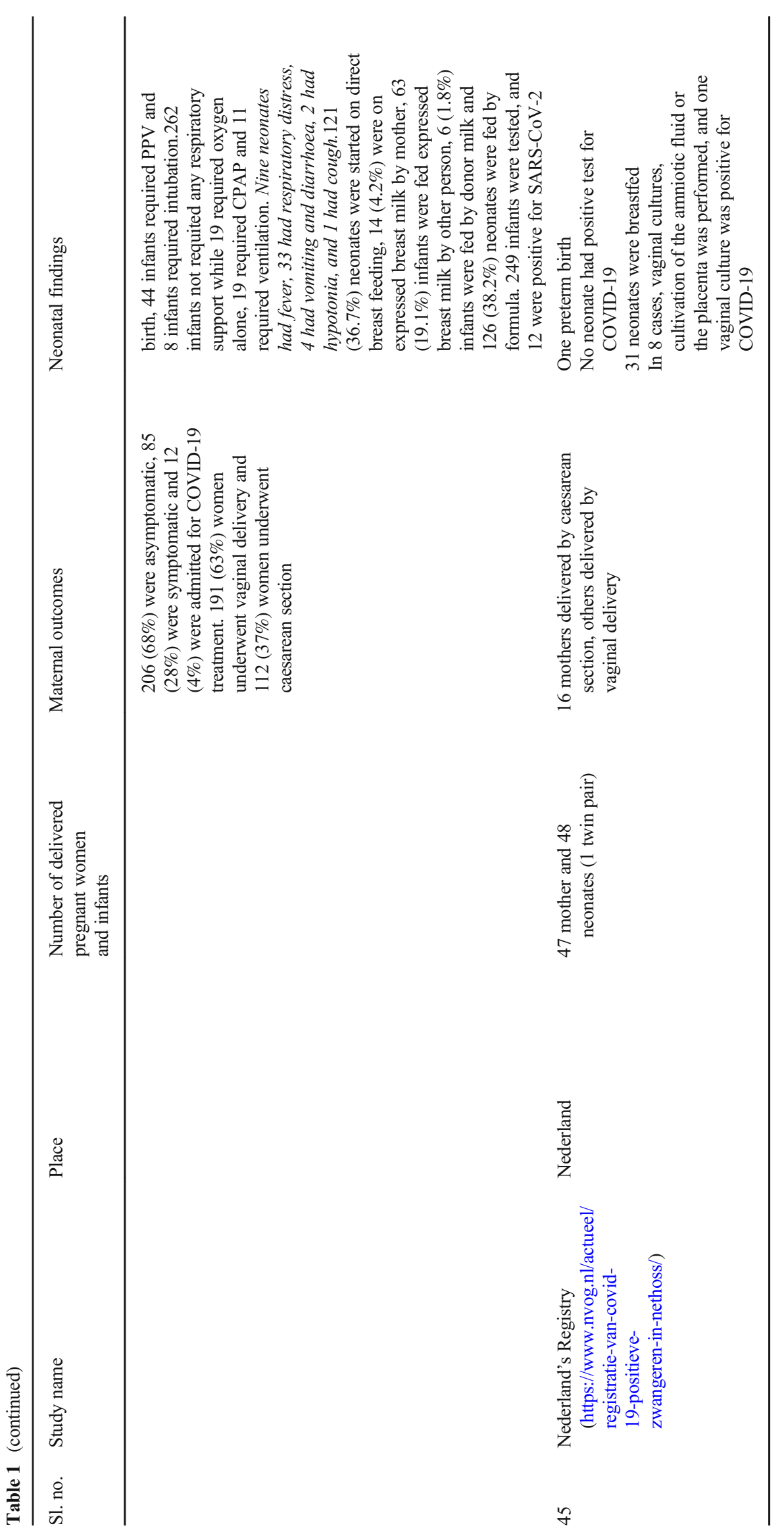


Fig. 2 Common tests available for coronavirus family

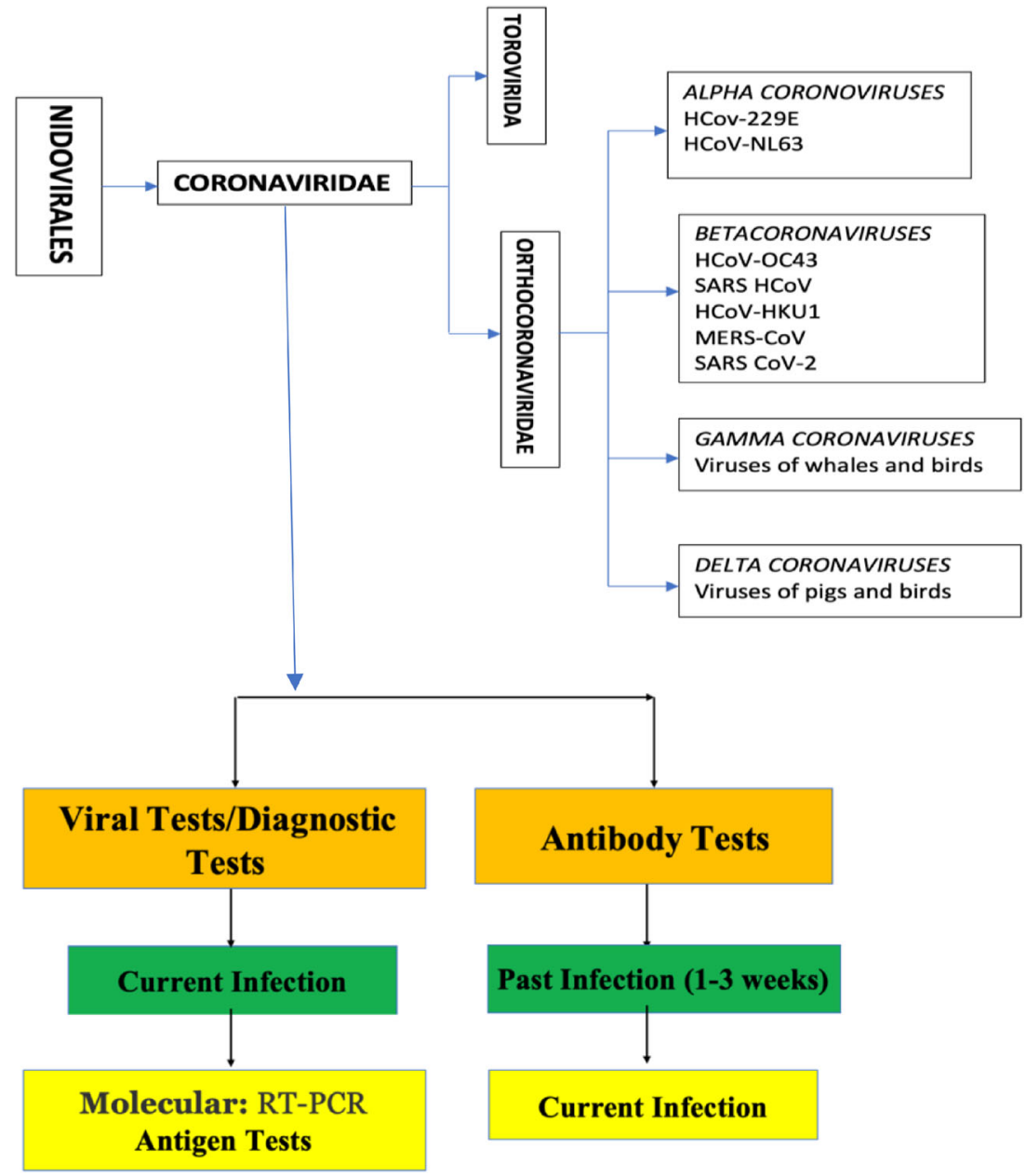

hypertensive disorders of pregnancy and may reflect an inflammatory state affecting placental physiology.

Complete blood count may show normal or low total while cell counts, decreased lymphocyte count and low platelet count. Various enzymes levels including creatinine kinase, lactate dehydrogenase, alanine aminotransferase and inflammatory markers (CRP, ferritin) have shown non-specific elevation $[20,23,30,52]$. Chest $\mathrm{X}$-ray findings can vary from normal in the initial phases to unilateral or bilateral patchy or ground glass involvement [53]. There are no characteristic Xray and CT features of neonatal COVID-19 till date because of limited data. USG chest could emerge to be a useful tool as it can be done at bedside and does not cause radiation exposure.

\section{Testing of pregnant women}

Based on resource availability, it may be useful to promote a general SARS-CoV-2 screening for pregnant women admitted to the hospital in order to prevent NICU outbreak. Universal screening of neonates, parents and healthcare workers can prevent spread of SARS-CoV-2 infection among the neonates admitted to a NICU even in an area with a high incidence of SARS-CoV-2 [54].

Many centres currently practise universal testing approach for pregnant women to determine optimal hospital isolation practices, use of personal protective equipment and neonatal care. However, the application of this strategy may not possible in resource limited settings or in cases of emergency delivery [55]. All pregnant women with clinical features attributable to COVID-19 should be tested by sending nasopharyngeal and/or oropharyngeal swab for RT-PCR testing. If symptoms persist and test reports are negative, ongoing isolation and repeat testing after 2-5 days is recommended. No emergency procedure or delivery should be delayed pending test results. All such cases should be considered suspect cases.

\section{Testing of the neonate}

Neonates born to mothers with COVID-19 infection within 14 days of delivery or up to 28 days after birth and neonates exposed to close contacts with COVID-19 infection should be tested [48]. If symptomatic, specimens should be collected as soon as possible. Asymptomatic neonates born to mothers 
with confirmed COVID-19 infection should be tested between 2 and $12 \mathrm{~h}$ after cleansing the face (https://www.cps.ca/en/ documents/position/nicu-care-for-infants-born-to-motherswith-suspected-or-proven-covid-19). Repeat testing after 23 days for positive cases and after 3-5 days for negative cases is recommended. If testing is not readily available, clinical monitoring should be done (https://www.aappublications. org/news/2020/07/22/newbornguidance072220). For diagnosing vertical transmission, it is important to follow a universally accepted definition for comparison and collation of data. One such classification system and case definition for SARS-CoV infection in pregnant women, foetuses and neonates has been proposed recently [49] (Table 2).

Guidelines from Chinese expert consensus, AAP/ American College of Obstetricians and Gynaecologists (ACOG)/Society for Maternal and Fetal Medicine (SMFM)/ Centers for Disease Control and Prevention (CDC) and RCOG/RCPCH are compared in Supplementary Table 1.

\section{Management}

Standardized testing protocol, prevention of spread from mother to child and providing optimal treatment to symptomatic neonates are the key areas in perinatal management of neonates with suspect/positive for COVID-19. It is advisable to cohort pregnant women who are positive for SARS-CoV-2 or as person under investigation (PUI) with ILI (influenza-like illness) (https://www.aappublications.org/news/2020/07/22/ newbornguidance072220, https://www.cps.ca/en/documents/ position/nicu-care-for-infants-born-to-mothers-withsuspected-or-proven-covid-19, https://www.rcog.org.uk/ globalassets/documents/guidelines/2020-04-17-coronaviruscovid-19-infection-in-pregnancy.pdf, https://www.cdc.gov/ coronavirus/2019-ncov/hcp/inpatient-obstetric-healthcareguidance.html, https://www.acog.org/clinical/clinicalguidance/practice-advisory/articles/2020/03/novelcoronavirus-2019) $[48,55,56]$. Ideally this should be done prior to hospital admission through telephonic or video consultation or at hospital entry. Antenatal steroids and magnesium sulphate for neuroprotection should be administered as per current guidelines. The pregnant women should wear mask to prevent the spread through droplet transmission. Neonatology team should discuss with the parents prior to delivery regarding delayed cord clamping, separation of the neonate from mother versus rooming-in and feeding options using a shared decision-making approach. The practices of rooming-in, PPE and mother-neonate separation are extremely variable according to different countries/ setting and guidelines from scientific societies or institutions. Thus, choices must be adapted to the local needs and situation. What is more important is to have a complete, open information to the family and a shared choice post-counselling. In real life, 'zero risk' does not exist, and decision should be based

Table 2 Suggested case definition for neonatal and maternal COVID-

infection in pregnant women, foetuses and neonates. Acta Obstet Gynecol 19 infection (adapted from Shah PS, Diambomba Y, Acharya G, Morris SK, Bitnun A. Classification system and case definition for SARS-CoV-2 Scand. 2020;99 [5]:565-568. doi:https://doi.org/10.1111/aogs.13870)

\begin{tabular}{|c|c|c|c|}
\hline C0VID-19 & Mother & $\begin{array}{l}\text { Congenital infection in foetus/perinatal } \\
\text { period }\end{array}$ & Acquired neonatal infection postnatal period \\
\hline Confirmed & $\begin{array}{l}\text { PCR - Positive in a respiratory } \\
\text { sample irrespective of } \\
\text { symptoms }\end{array}$ & $\begin{array}{l}\text { PCR - Positive in sample collected within } \\
\text { first } 12 \mathrm{~h} \text { of birth or amniotic fluid } \\
\text { collected prior to rupture of membrane }\end{array}$ & $\begin{array}{l}\text { PCR - Positive at birth AND at } 24-48 \mathrm{~h} \text { of age AND } \\
\text { alternate explanation for clinical features excluded }\end{array}$ \\
\hline Probable & & $\begin{array}{l}\text { PCR - Positive in nasopharyngeal swab at } \\
\text { birth (AND) placental swab from foetal } \\
\text { side of placenta }\end{array}$ & $\begin{array}{l}\text { PCR - Positive at birth but not at } 24-48 \mathrm{~h} \text { of age AND } \\
\text { alternate explanation for clinical features excluded }\end{array}$ \\
\hline Possible & Symptomatic but no testing done & $\begin{array}{l}\text { PCR - Negative AND presence of } \\
\text { anti-SARS-CoV-2 IgM Ab - Positive } \\
\text { within first } 12 \mathrm{~h} \text { of birth }\end{array}$ & $\begin{array}{l}\text { PCR - Neonatal sample negative at birth AND PCR - } \\
\text { positive in any of maternal vaginal/placental/skin swab } \\
\text { at birth AND alternate explanation for clinical features } \\
\text { excluded }\end{array}$ \\
\hline Unlikely & $\begin{array}{l}\text { No detection of the virus by PCR } \\
\text { in a respiratory sample and no } \\
\text { other cause identified }\end{array}$ & $\begin{array}{l}\text { No detection of the virus by PCR AND } \\
\text { antibody testing not done }\end{array}$ & $\begin{array}{l}\text { PCR - Negative in nasopharyngeal swab at birth OR in } \\
\text { any of maternal vaginal/placental/cord/neonatal } \\
\text { nasopharyngeal/skin swab at birth AND alternate } \\
\text { explanation for clinical features not identified }\end{array}$ \\
\hline $\begin{array}{l}\text { Not } \\
\text { Infected }\end{array}$ & $\begin{array}{l}\text { No detection of the virus by PCR } \\
\text { in a respiratory sample and } \\
\text { other cause identified }\end{array}$ & $\begin{array}{l}\text { No detection of the virus by PCR AND } \\
\text { antibody testing negative }\end{array}$ & $\begin{array}{l}\text { PCR - Negative in nasopharyngeal swab at birth OR in } \\
\text { any of maternal vaginal/placental/cord/neonatal } \\
\text { nasopharyngeal/skin swab at birth AND alternate } \\
\text { explanation for clinical features identified }\end{array}$ \\
\hline
\end{tabular}

Recommended samples

Mother: nasopharyngeal/ nasal/broncho-alveolar lavageFoetus: foetal or placental tissue

Neonate: umbilical cord blood or neonatal blood, amniotic fluid, nasopharyngeal swab 
after evaluating the risk-benefit ratio, resource availability, feasibility and parental preference $[55,56]$.

Precautions and PPE In the current context of pandemic, triaging pregnant women as suspect, positive or negative cases will optimize utilization of resources.

Contact and droplet precautions are recommended for routine encounters with confirmed or suspect neonates with COVID-19 infection. These include gown, gloves, standard procedural mask and eye protection (face shield or goggles). Airborne, contact and droplet precautions are recommended for procedures including bag and mask ventilation, intubation, suctioning and neonates on any form of respiratory support. The PPE includes gown, gloves, N95 respiratory mask with eye protection or air-purifying respirator (powered airpurifying respiratory (PAPR) (https:/www.aappublications. org/news/2020/07/22/newbornguidance072220).

Delivery room Resuscitation of neonates born to mothers with confirm or suspected COVID-19 disease should be in accordance with the latest NRP guidelines (https:/www.aappublications.org/ news/2020/07/22/newbornguidance072220). Delayed cord clamping (DCC) has significant benefits in term and preterm neonates, but the small risk of viral transmission through cord blood does exist. As per existing practice, DCC may be considered unless contraindicated, after discussion with families [48]. Resuscitation should be in a separate room and overcrowding should be avoided. If separate room is not available, the neonatal resuscitation corner should be at least $6 \mathrm{ft}$ away from the delivery cot. Resuscitation may involve suctioning, providing PPV or intubation; hence, the providers should don airborne, contact and droplet level-PPE [48]. DR resuscitative manoeuvres are at high risk of aerosolization; also there is risk of transmission from maternal blood, amniotic fluid and other body fluids. Noninvasive ventilation provided during resuscitation may significantly increase this risk like in the NICU as neonatal CPAP and NIV are almost always invariably associated with 40-50\% leaks through the mouth [57]. Therefore, PPE should be a norm in DR in the present pandemic era for all the personnel attending to the mother and her neonate. Based on adult data, the risk of acquiring a viral infection is higher during endotracheal intubation compared with manual ventilation (bag-mask ventilation) [58]. The use of bacterial/viral filters in the exhalation limb of $\mathrm{T}$-piece may be effective in reducing viral dispersion and is recommended by many scientific societies. With close monitoring, it may be reasonable to use smaller filters (approximately $10 \mathrm{~mL}$ of dead space) in neonates with birth weight $>2 \mathrm{~kg}$.

\section{Infants needing NICU care}

The neonates born to positive mothers should be nursed in an incubator and transported to the NICU by a dedicated team wearing PPE. Ideally, the neonate should be kept in negative pressure isolation rooms or in rooms with high efficiency particulate air filters (HEPA). Staff should handle the baby with isolation precautions and PPE, and such staff should not move to other sections of the NICU. If the NICU does not have a single-room design, open-bay NICU's should have at least 3 sections, first room for babies born to COVID-19 positive/ suspect mothers, second for babies who are born to COVID19 negative asymptomatic mothers and third room for babies who were in room one but have tested negative twice. The staff and workforce should also follow the same flow, with dedicated team of healthcare workers (HCW) for each section. It is important to remember that NICU should be reserved only for those neonates needing intensive care. A general NICU admission policy due to positive/suspect COVID status may lead to shortage of beds and will also contribute to false epidemiological data and overestimation of the disease severity in neonatal population [59].

Testing of the neonate should be performed between 2 and $12 \mathrm{~h}$ after birth. If negative, a repeat test should be performed after 3-5 days. If the neonate is requiring prolonged NICU stay and both tests are negative, the neonate can be shifted to a separate room to prevent ongoing risk of transmission from other babies. Symptomatic and supportive therapy are the main principles of management as no specific antiviral agent is approved for use in neonates.

\section{Respiratory management}

Although neonatal COVID can present with varied symptoms involving cardiovascular, GIT or CNS systems, respiratory distress is the commonest system. However, neonates are more likely to need respiratory support due to other conditions such as prematurity, sepsis, respiratory distress syndrome, and transient tachypnoea of newborn rather than due to COVID19 pneumonia. Epidemiologically, the priority should be to diagnose neonatal ARDS according to Montreux definition and use it to classify disease severity [60].

Respiratory management practices should be evidence based for providing optimal support to the neonate and also protecting $\mathrm{HCW}$ from the virus. The main concern related to respiratory support in neonates with suspected or confirmed COVID-19 infection is the generation of aerosol-containing particles that can lead to disease spread. The data related to respiratory management of neonates with COVID-19 infection is limited, as majority of neonates have tested negative or have been asymptomatic. Thus, it seems reasonable to have a practical, physiology-based approach for these neonates as we await more evidence.

Non-invasive support CPAP remains the standard therapy in managing neonates with respiratory distress in the NICU including those with COVID-19. Heated humidified high flow 
nasal cannula (HHHFNC) may lead to higher dispersion of virus due to the presence of higher leak around the nose and should be avoided. A study by Simonds et al. showed that air dispersion during NIPPV generates droplets of $>10 \mu \mathrm{m}$ in size, which are more likely to deposit on local surfaces within a short distance [61]. CPAP with a close circuit provided by the ventilator may be safer as it has lesser degree of aerosol generation, and the same machine and circuit can be used for mechanical ventilation if the patient deteriorates. However infant flow driver, variable flow CPAP should be avoided as one limb is open to the exterior and may be a source of spread. Precautions during use of CPAP for neonates include proper PPE measures for HCW (airborne, droplet and contact-level PPE), optimal fitting of the interface, adequate spacing/ ventilation in room and regular disinfection of surfaces/baby environment. The CPAP tubing and water reservoir should be replaced every week and discarded appropriately. Disposable circuits should be preferred, and one should use filters on the expiratory limb (at least) of circuits as is stated by many scientific societies.

Invasive support Endotracheal intubation is an aerosol generating procedure and should be performed by skilled person wearing adequate PPE. Both cuffed and uncuffed tube may be used for intubation. Low cuff pressure has been demonstrated to be safe in various studies [88, 89]. Video laryngoscope should be preferred as it allows easy access to the airway and avoids close contact. If available, closed in-line suctioning and use of hydrophobic filter at the exhalation port is recommended both during non-invasive and invasive respiratory support. Use of appropriately sized, endotracheal tube is recommended to minimize leak, and oral intubation should be preferred over nasal intubation [90]. Mode of ventilation and strategy for weaning should be based on disease process and current practice.

\section{Stable neonates not requiring NICU admission}

Stable neonates born to confirm/suspect COVID-19 mothers who are stable can be roomed-in together in a negative pressure isolation room. The potential benefit of temporary maternal and newborn separation in decreasing neonatal infection versus the issues related to infant separation should be discussed with the family prior to delivery. If mother and baby are roomed-in, an additional caregiver who is non COVID-19 exposed and asymptomatic could be permitted to care for the baby. The mother should wear N-95 mask and practice meticulous hand hygiene. The infant should be placed at least $6 \mathrm{ft}$ from the mother. Breast milk has numerous benefits, and there is little data to suggest that virus transmission occurs via breast milk $[25,26]$. Expressed breast milk can be safely fed to the neonate by the designated caregiver after boiling. The breast pump components and paladai/feeding bottles should be thoroughly disinfected after each use. Skin-to-skin contact should be avoided due to risk of transmission of virus. In case the mother wishes to directly breast feed the infant, she should follow strict hand hygiene and wear mask at all times. The neonate should be monitored regularly for vitals and respiratory symptoms. The neonate can be discharged as per routine discharge criteria if asymptomatic and after 2 consecutive negative tests for COVID-19. A comprehensive approach for the perinatal and postnatal management, discharge and follow-up of neonates has been summarized in Fig. 2.

\section{Neonatal transport in suspect or positive case}

Transport of a sick infant involves meticulous planning and should be efficient, safe and timely. Data reported by the Neonatal Transport Study Group of the Italian Society of Neonatology showed a significant increase in the median time to complete transport from $120 \mathrm{~min}$ previously to $240 \mathrm{~min}$ in the current COVID-19 period. The common reasons attributable for this delay include donning and doffing of PPE protocols, disinfection of ambulance, devices and delays in obtaining necessary documentation [91].

It is important to have a clear communication with the referring unit prior to transport regarding the infant's or mother's recent COVID status. The shortest route of transport and transit modifications inside referring hospitals should be established (e.g. alternative passage or lifts for transfer of suspect/confirmed cases). The ambulance should be equipped with adequate PPE, and number of team members should be restricted depending on the situation. Members of the transport team must wear protective gear including N95 respirator, disposable gown, visor/goggles, face-shield and shoe cover. The equipment used for stabilization should be placed in airtight plastic containers for reuse during the transport. The infant must be transported in an incubator, and unnecessary opening of portholes should be avoided. On arriving at the destination, another team from the tertiary hospital can receive the infant from the ambulance (after donning PPE) and escort to the NICU. Once the neonate is safely transferred to the NICU, cleaning of the transport incubator, monitors, syringe pumps and ventilator must be done with disinfectant wipes or paper cloth soaked in 70\% ethyl alcohol or other appropriate disinfectant. Other equipment (i.e. masks, laryngoscope, selfinflating bag) should be sterilized according to standard institutional policy. Lastly, the vehicle should be sanitized prior to the next transport. Road transports should be preferred if possible, and the ambulance should not have any open passage/ windows between the health compartment and driver. Having a clear institution-based standard operating procedure will 
minimize delays and ensure safe transport for the infant and the crew [92].

Thus, the overall prognosis of neonates born to COVID19-positive mothers is favourable. Risk of transmission is low, and most neonates are asymptomatic. Possible protective mechanisms include lower ACE2 expression (SARS-CoV-2 receptor), less robust proinflammatory cytokine response and stronger innate immune system $[93,94]$.

Limitations This review is based on mostly retrospective reports, reviews and consensus guidelines whose quality may be suboptimal due to fast-tracked publications considering the unexpected nature of pandemic. These recommendations may change at a later stage, once more robust evidence is available.

Future research considerations There is a need for large prospective multi-centre international registries of neonatal SARS-CoV-2 infections to better understand the epidemiology, the detail and the possibility of interventions for neonatal cases such as registries by AAP and EPICENTRE Registry [95].

The following key points summarize practical considerations for perinatal COVID-19:

- Criteria for testing pregnant women should be same as for general population. Universal testing prior to delivery may help in deciding optimal isolation practices.

- Antenatal steroid and magnesium sulphate should be given as per current guidelines.

- Mode of delivery should be as per obstetric/foetal indication irrespective of COVID-19 status

- Use dedicated delivery room and operating room for confirmed or suspected COVID-19 pregnant women. Perform neonatal resuscitation in a separate room or at least $6 \mathrm{ft}$ away from delivery area as per NRP.

- Delayed cord clamping should be done as per current guidelines after discussion with family.

- Practice airborne, droplet and contact precautions with PPE for performing deliveries and neonatal resuscitation.

- Video laryngoscope should be preferred for intubation, and one should avoid giving medications through endotracheal tube.

- Immediate bathing should be avoided because of risk of hypothermia.

- Ensure proper disposal of all PPE prior to exiting the room.

- Neonates born to positive mothers should be initially tested between 2 and $12 \mathrm{~h}$ after cleansing the face.

- For infants needing respiratory support, ensure optimal fitting of interface, adequate spacing between beds, use of adequate PPE and frequent disinfection of baby environment every 2-4 hourly.
- For infants on mechanical ventilation, use appropriate size endotracheal tube, in-line suctioning, adequate PPE and small hydrophobic filter at exhalation port.

- For infants not needing admission, decision to room-in with mother should be based on shared decision-making principle.

- Infant can be fed expressed breast milk by healthy caregiver.

- If roomed-in, infant crib should be placed at least $6 \mathrm{ft}$ away from the mother. Mother should ensure hand hygiene and wear mask.

- Neonatal BCG vaccination can be continued in countries or settings with a high incidence of tuberculosis as per existing practice [61].

- Stools and diapers should be considered infectious waste and disposed with all necessary precautions as per protocol.

- Mobile phone use should be restricted in clinical areas.

Supplementary Information The online version contains supplementary material available at https://doi.org/10.1007/s00431-020-03866-3.

Acknowledgements We are grateful to Shivani Bhan for infographics and other technical help.

Authors' contributors VV and AP did the literature search, designed and/ or debated the series of articles/ studies, made editorial comments and assure the validity of the content. VV, AnP, SB and AP drafted this article. AP, AnP and SB did the critical appraisal of the manuscript. All authors accepted the final manuscript.

Data availability NA

\section{Compliance with ethical standards}

Conflict of interest The authors declare that they have no conflict of interest.

Ethics approval NA

Consent to participate NA

Consent for publication Yes we consent for publication.

Code availability NA

\section{References}

1. Banerjee A, Kulcsar K, Misra V, Frieman M, Mossman K (2019) Bats and coronaviruses. Viruses. 11(1):41

2. Chen Y, Liu Q, Guo D (2020) Emerging coronaviruses: genome structure, replication, and pathogenesis. J Med Virol 92(4):418-423

3. Cheng VC, Lau SK, Woo PC, Yuen KY (2007) Severe acute respiratory syndrome coronavirus as an agent of emerging and reemerging infection. Clin Microbiol Rev 20(4):660-694 
4. Zumla A, Hui DS, Perlman S (2015) Middle East respiratory syndrome. Lancet 386(9997):995-1007

5. Chan JF, To KK, Tse H, Jin DY, Yuen KY (2013) Interspecies transmission and emergence of novel viruses: lessons from bats and birds. Trends Microbiol 21(10):544-555

6. Zhu N, Zhang D, Wang W, Li X, Yang B, Song J, Zhao X, Huang B, Shi W, Lu R, Niu P (2020) A novel coronavirus from patients with pneumonia in China, 2019, New England journal of medicine. 24

7. Gorbalenya AE (2020) Severe acute respiratory syndrome-related coronavirus-the species and its viruses, a statement of the coronavirus study group. BioRxiv. 1

8. Lu R, Zhao X, Li J, Niu P, Yang B, Wu H, Wang W, Song H, Huang B, Zhu N, Bi Y (2020) Genomic characterisation and epidemiology of 2019 novel coronavirus: implications for virus origins and receptor binding. Lancet 395(10224):565-574

9. Zhou P, Yang XL, Wang XG, Hu B, Zhang L, Zhang W, Si HR, Zhu Y, Li B, Huang CL, Chen HD (2020) A pneumonia outbreak associated with a new coronavirus of probable bat origin. Nature. 579(7798):270-273

10. Lam TT, Shum MH, Zhu HC, Tong YG, Ni XB, Liao YS, Wei W, Cheung WY, Li WJ, Li LF, Leung GM (2020) Identifying SARSCoV-2 related coronaviruses in Malayan pangolins. Nature. 26:1-6

11. Wang D, Hu B, Hu C, Zhu F, Liu X, Zhang J, Wang B, Xiang H, Cheng Z, Xiong Y, Zhao Y (2020) Clinical characteristics of 138 hospitalized patients with 2019 novel coronavirus-infected pneumonia in Wuhan, China. Jama 323(11):1061-1069

12. Li Q, Guan X, Wu P, Wang X, Zhou L, Tong Y, Ren R, Leung KS, Lau EH, Wong JY, Xing X (2020) Early transmission dynamics in Wuhan, China, of novel coronavirus-infected pneumonia. N Engl J Med

13. Hoffmann M, Kleine-Weber H, Schroeder S et al (2020) SARSCoV-2 cell entry depends on ACE2 and TMPRSS2 and is blocked by a clinically proven protease inhibitor. Cell 181(2):271-280.e8. https://doi.org/10.1016/j.cell.2020.02.052

14. Lu CW, Liu XF, Jia ZF (2020) 2019-nCoV transmission through the ocular surface must not be ignored. Lancet (London, England) 395(10224):e39

15. Zhang H, Kang Z, Gong H, Xu D, Wang J, Li Z, Cui X, Xiao J, Meng T, Zhou W, Liu J (2020) The digestive system is a potential route of 2019-nCov infection: a bioinformatics analysis based on single-cell transcriptomes. BioRxiv. 1

16. Li M, Chen L, Zhang J, Xiong C, Li X (2020) The SARS-CoV-2 receptor ACE2 expression of maternal-fetal interface and fetal organs by single-cell transcriptome study. PLoS One 15(4): e0230295. Published 2020 Apr 16. https://doi.org/10.1371/ journal.pone. 0230295

17. Baud D, Greub G, Favre G, Gengler C, Jaton K, Dubruc E, Pomar L (2020) Second-trimester miscarriage in a pregnant woman with SARS-CoV-2 infection. JAMA. 323(21):2198-2200. https://doi. org/10.1001/jama.2020.7233

18. Schwartz DA (2020) An analysis of 38 pregnant women with COVID-19, their newborn infants, and maternal-fetal transmission of SARS-CoV-2: maternal coronavirus infections and pregnancy outcomes. Arch Pathol Lab Med 17

19. Raschetti R, Vivanti AJ, Vauloup-Fellous C, Loi B, Benachi A, de Luca D (2020) Synthesis and systematic review of reported neonatal SARS-CoV-2 infections. Nat Commun 11:5164. https://doi.org/ 10.1038/s41467-020-18982-9

20. Zeng L, Xia S, Yuan W, Yan K, Xiao F, Shao J, Zhou W (2020) Neonatal early-onset infection with SARS-CoV-2 in 33 neonates born to mothers with COVID-19 in Wuhan, China. JAMA Pediatr 26

21. Yu N, Li W, Kang Q, Xiong Z, Wang S, Lin X, Liu Y, Xiao J, Liu H, Deng D, Chen S (2020) Clinical features and obstetric and neonatal outcomes of pregnant patients with COVID-19 in Wuhan,
China: a retrospective, single-centre, descriptive study. Lancet Infect Dis 24

22. Zeng H, Xu C, Fan J, Tang Y, Deng Q, Zhang W, Long X (2020) Antibodies in infants born to mothers with COVID-19 pneumonia. Jama. 26

23. Dong L, Tian J, He S, Zhu C, Wang J, Liu C, Yang J (2020) Possible vertical transmission of SARS-CoV-2 from an infected mother to her newborn. Jama 26

24. Alzamora MC, Paredes T, Caceres D, Webb CM, Valdez LM, La Rosa M (2020) Severe COVID-19 during pregnancy and possible vertical transmission [published online ahead of print, 2020 Apr 18]. Am J Perinatol. https://doi.org/10.1055/s-0040-1710050

25. Kirtsman M, Diambomba Y, Poutanen SM, et al. (2020) Probable congenital SARS-CoV-2 infection in a neonate born to a woman with active SARS-CoV-2 infection [published online ahead of print, 2020 May 14]. CMAJ. cmaj.200821. https://doi.org/10. 1503/cmaj.200821

26. Groß R, Conzelmann C, Müller JA, et al. (2020) Detection of SARS-CoV-2 in human breastmilk [published online ahead of print, 2020 May 21]. Lancet. S0140-6736(20)31181-8. https:// doi.org/10.1016/S0140-6736(20)31181-8

27. Zamaniyan M, Ebadi A, Aghajanpoor Mir S, Rahmani Z, Haghshenas M, Azizi S (2020) Preterm delivery in pregnant woman with critical COVID-19 pneumonia and vertical transmission. Prenat Diagn 17

28. Di Mascio D, Khalil A, Saccone G, Rizzo G, Buca D, Liberati M, Vecchiet J, Nappi L, Scambia G, Berghella V, D’Antonio F (2020) Outcome of coronavirus spectrum infections (SARS, MERS, COVID 1-19) during pregnancy: a systematic review and metaanalysis. Am J Obstet Gynecol MFM 25:100107

29. Zhu H, Wang L, Fang C, Peng S, Zhang L, Chang G, Xia S, Zhou W (2020) Clinical analysis of 10 neonates born to mothers with 2019-nCoV pneumonia. Transl Pediatr 9(1):51-60

30. Li N, Han L, Peng M, Lv Y, Ouyang Y, Liu K, Yue L, Li Q, Sun G, Chen L, Yang L (2020) Maternal and neonatal outcomes of pregnant women with COVID-19 pneumonia: a case-control study. Clin Infect Dis 1

31. Wu Z, McGoogan JM (2020) Characteristics of and important lessons from the coronavirus disease 2019 (COVID-19) outbreak in China: summary of a report of 72314 cases from the Chinese Center for Disease Control and Prevention. Jama. 24

32. Costa S, Posteraro B, Marchetti S, et al. (2020) Excretion of SARSCoV-2 in human breast milk [published online ahead of print, 2020 Jun 2]. Clin Microbiol Infect. S1198-743X(20)30304-9. https:// doi.org/10.1016/j.cmi.2020.05.027

33. Chambers C, Krogstad P, Bertrand K, et al. (2020) Evaluation for SARS-CoV-2 in Breast Milk From 18 Infected Women [published online ahead of print, 2020 Aug 19]. JAMA. e2015580. https://doi. org/10.1001/jama.2020.15580

34. Liu Y, Gayle AA, Wilder-Smith A, Rocklöv J (2020) The reproductive number of COVID-19 is higher compared to SARS coronavirus. J Travel Med 1

35. Chen J (2020) Pathogenicity and transmissibility of 2019-nCoV-a quick overview and comparison with other emerging viruses. Microbes Infect 4

36. Breslin N, Baptiste C, Gyamfi-Bannerman C, Miller R, Martinez R, Bernstein K, Ring L, Landau R, Purisch S, Friedman AM, Fuchs K (2020) COVID-19 infection among asymptomatic and symptomatic pregnant women: two weeks of confirmed presentations to an affiliated pair of New York City hospitals. Am J Obstet Gynecol MFM 9:100118

37. Liu D, Li L, Wu X, Zheng D, Wang J, Yang L, Zheng C (2020) Pregnancy and perinatal outcomes of women with coronavirus disease (COVID-19) pneumonia: a preliminary analysis. Am J Roentgenol 18:1-6 
38. Liu Y, Chen H, Tang K, Guo Y (2020) Clinical manifestations and outcome of SARS-CoV-2 infection during pregnancy. J Inf Secur 4

39. Chen S, Huang B, Luo DJ, Li X, Yang F, Zhao Y, Nie X, Huang BX (2020) Pregnant women with new coronavirus infection: a clinical characteristics and placental pathological analysis of three cases. Zhonghua bing li xue za zhi= Chin J Pathol 49:E005

40. Zhang L, Jiang Y, Wei M, Cheng BH, Zhou XC, Li J, Tian JH, Dong L, Hu RH (2020) Analysis of the pregnancy outcomes in pregnant women with COVID-19 in Hubei Province. Zhonghua fu chan ke za zhi 55:E009

41. Wang X, Zhou Z, Zhang J, Zhu F, Tang Y, Shen X, Shen X (2020) A case of 2019 Novel coronavirus in a pregnant woman with preterm delivery. Clin Infect Dis

42. Liu W, Wang Q, Zhang Q, Chen L, Chen J, Zhang B, Lu Y, Wang S, Xia L, Huang L, Wang K. Coronavirus disease 2019 (COVID19) during pregnancy: a case series

43. Chen Y, Peng H, Wang L, Zhao Y, Zeng L, Gao H, Liu Y (2020) Infants born to mothers with a new coronavirus (COVID-19). Front Pediatr 8:104

44. Mimouni F, Lakshminrusimha S, Pearlman SA, Raju T, Gallagher PG, Mendlovic J (2020) Perinatal aspects on the covid-19 pandemic: a practical resource for perinatal-neonatal specialists. J Perinatol 40:820-826. https://doi.org/10.1038/s41372-020-0665-6

45. Coronado Munoz A, Nawaratne U, McMann D, Ellsworth M, Meliones J, Boukas K (2020) Late-onset neonatal sepsis in a patient with Covid-19. N Engl J Med 382(19):e49. https://doi.org/10.1056/ NEJMc2010614

46. Centers for Disease Control and Prevention. Interim guidelines for collecting, handling, and testing clinical specimens from persons under investigation (PUIs) for coronavirus disease 2019 (COVID19). February 14, 2020. https://www.cdc.gov/coronavirus/2019$\mathrm{nCoV} /$ lab/guidelines-clinical-specimens.html (Accessed on March 15, 2020)

47. World Health Organization. Laboratory testing for coronavirus disease ( COVID-19) in suspected human cases: interim guidance, 19 March 2020. World Health Organization; 2020

48. Trevisanuto D, Moschino L, Doglioni N, Roehr CC, Gervasi MT, Baraldi E (2020) Neonatal resuscitation where the mother has a suspected or confirmed novel coronavirus (SARS-CoV-2) infection: suggestion for a pragmatic action plan. Neonatology $117(2)$ : 133-140. https://doi.org/10.1159/000507935

49. Shah PS, Diambomba Y, Acharya G, Morris SK, Bitnun A (2020) Classification system and case definition for SARS-CoV-2 infection in pregnant women, fetuses, and neonates. Acta Obstet Gynecol Scand 99(5):565-568. https://doi.org/10.1111/aogs.13870

50. Guo L, Ren L, Yang S, Xiao M, Chang D, Yang F, Dela Cruz CS, Wang Y, Wu C, Xiao Y, Zhang L (2020) Profiling early humoral response to diagnose novel coronavirus disease (COVID-19). Clin Infect Dis 21

51. Shanes ED, Mithal LB, Otero S, Azad HA, Miller ES, Goldstein JA (2020) Placental pathology in COVID-19. medRxiv. 1

52. Wang S, Guo L, Chen L, et al. (2020) A case report of neonatal COVID-19 infection in China. Clin Infect Dis :ciaa225 (e-pub ahead of print). https://doi.org/10.1093/cid/ciaa225

53. Shi H, Han X, Jiang N, Cao Y, Alwalid O, Gu J, Fan Y, Zheng C (2020) Radiological findings from 81 patients with COVID-19 pneumonia in Wuhan, China: a descriptive study. Lancet Infect Dis 24

54. Cavicchiolo ME, Trevisanuto D, Lolli E, Mardegan V, Saieva AM, Franchin E, Plebani M, Donato D, Baraldi E (2020) Universal screening of high-risk neonates, parents, and staff at a neonatal intensive care unit during the SARS-CoV-2 pandemic [published online ahead of print, 2020 Aug 7]. Eur J Pediatr 1-7. https://doi. org/10.1007/s00431-020-03765-7

55. Chandrasekharan $\mathrm{P}$, Vento $\mathrm{M}$, Trevisanuto D, Partridge E, Underwood MA, Wiedeman J, Katheria A, Lakshminrusimha S
(2020) Neonatal resuscitation and postresuscitation care of infants born to mothers with suspected or confirmed SARS-CoV-2 infection. Am J Perinatol 8

56. Yeo KT, Oei JL, De Luca D, et al. (2020) Review of guidelines and recommendations from 17 countries highlights the challenges that clinicians face caring for neonates born to mothers with COVID-19 [published online ahead of print, 2020 Jul 27]. Acta Paediatr. https://oi.org/10.1111/apa.15495

57. Centorrino R, Dell'Orto V, Gitto E, Conti G, De Luca D (2019) Mechanics of nasal mask-delivered HFOV in neonates: a physiologic study. Pediatr Pulmonol 54(8):1304-1310. https://doi.org/10. 1002/ppul.24358

58. Chan MT, Chow BK, Lo T, Ko FW, Ng SS, Gin T, Hui DS (2018) Exhaled air dispersion during bag-mask ventilation and sputum suctioning-implications for infection control. Sci Rep 8(1):1-8

59. De Luca D (2020) Managing neonates with respiratory failure due to SARS-CoV-2. Lancet Child Adolesc Health 4(4):e8. https://doi. org/10.1016/S2352-4642(20)30073-0

60. De Luca D, van Kaam AH, Tingay DG et al (2017) The Montreux definition of neonatal ARDS: biological and clinical background behind the description of a new entity. Lancet Respir Med 5(8): 657-666. https://doi.org/10.1016/S2213-2600(17)30214-X

61. Simonds AK, Hanak A, Chatwin M, Morrell M, Hall A, Parker KH, Siggers JH, Dickinson RJ (2010) Evaluation of droplet dispersion during non-invasive ventilation, oxygen therapy, nebuliser treatment and chest physiotherapy in clinical practice: implications for management of pandemic influenza and other airborne infections. Health Technol Assess (Winchester, England) 14(46):131-172

62. Kamali Aghdam M, Jafari N, Eftekhari K (2020) Novel coronavirus in a 15-day-old neonate with clinical signs of sepsis, a case report. Infect Dis Ther 30:1-3

63. Díaz CA, Maestro ML, Pumarega MT, Antón BF, Alonso CP (2020) First case of neonatal infection due to COVID 19 in Spain. Anales de Pediatría (English Edition). 1

64. Zhang ZJ, Yu XJ, Fu T, Liu Y, Jiang Y, Yang BX, Bi Y (2020) Novel coronavirus infection in newborn babies under 28 days in China. Eur Respir J 1

65. Ferrazzi E, Frigerio L, Savasi V, Vergani P, Prefumo F, Barresi S, Bianchi S, Ciriello E, Facchinetti F, Gervasi MT, Iurlaro E. Mode of delivery and clinical findings in COVID-19 infected pregnant women in Northern Italy

66. Salvatori G, De Rose DU, Concato C, Alario D, Olivini N, Dotta A, Campana A (2020) Managing COVID-19-positive maternal-infant dyads: an Italian experience. Breastfeed Med 21

67. Nie R, Wang SS, Yang Q, Fan CF, Liu YL, He WC, Jiang M, Liu $\mathrm{CC}$, Zeng WJ, Wu JL, Oktay K (2020) Clinical features and the maternal and neonatal outcomes of pregnant women with coronavirus disease 2019. medRxiv. 1

68. Khan S, Jun L (2020) Nawsherwan, et al. Association of COVID19 infection with pregnancy outcomes in healthcare workers and general women. Clin Microbiol Infect S1198-743X(20) 30180-4 (e-pub ahead of print). https://doi.org/10.1016/j.cmi.2020.03.034

69. Hantoushzadeh S, Shamshirsaz AA, Aleyasin A, Seferovic MD, Aski SK, Arian SE, Pooransari P, Ghotbizadeh F, Aalipour S, Soleimani Z, Naemi M (2020) Maternal death due to COVID-19 disease. Am J Obstet Gynecol 28

70. Yan J, Guo J, Fan C, Juan J, Yu X, Li J, Feng L, Li C, Chen H, Qiao Y, Lei D (2020) Coronavirus disease 2019 (COVID-19) in pregnant women: a report based on 116 cases. Am J Obstet Gynecol 23

71. Fan C, Lei D, Fang C, et al. (2020) Perinatal transmission of COVID-19 associated SARS-CoV-2: should we worry? Clin Infect Dis :ciaa226 (e-pub ahead of print). https://doi.org/10.1093/ cid/ciaa226

72. Xu L, Yang Q, Shi H, Lei S, Liu X, Zhu Y, Wu Q, Ding X, Tian Y, $\mathrm{Hu}$ Q, Chen F (2020) Clinical presentations and outcomes of 
SARS-CoV-2 infected pneumonia in pregnant women and health status of their neonates. Sci Bull 28

73. Lu Zhang, Lan Dong, Lei Ming et al. Severe acute respiratory syndrome coronavirus 2(SARS-CoV-2) infection during late pregnancy: a report of 18 patients from Wuhan, China, 28 April 2020, PREPRINT (Version 2) available at Research Square [+https://doi. org/10.21203/rs.3.rs-18247/v2+]

74. Yang P, Wang X, Liu P, Wei C, He B, Zheng J, Zhao D (2020) Clinical characteristics and risk assessment of newborns born to mothers with COVID-19. J Clin Virol 10:104356

75. Li Y, Zhao R, Zheng S, Chen X, Wang J, Sheng X, Zhou J, Cai H, Fang Q, Yu F, Fan J Early release-lack of vertical transmission of severe acute respiratory syndrome coronavirus 2 . China

76. Lee DH, Lee J, Kim E, Woo K, Park HY, An J (2020) Emergency caesarean section on severe acute respiratory syndrome coronavirus 2 (SARS- CoV-2) confirmed patient. Korean J Anesthesiol (e- pub ahead of print). https://doi.org/10.4097/kja.20116

77. Gidlöf S, Savchenko J, Brune T, Josefsson H (2020) COVID-19 in pregnan- cy with comorbidities: more liberal testing strategy is needed. Acta Obstet Gynecol Scand (e-pub ahead of print). https://doi.org/10.1111/aogs.13862

78. Lowe B, Bopp B (2020) COVID-19 vaginal delivery-a case report. Aust N Z J Obstet Gynaecol 15

79. Song L, Xiao W, Ling K, Yao S, Chen X (2020) Anesthetic management for emergent cesarean delivery in a parturient with recent diagnosis of coronavirus disease 2019 (COVID-19): a case report. Transl Perioper Pain Med 7:234-237

80. Chen S, Liao E, Shao Y (2020) Clinical analysis of pregnant women with 2019 novel coronavirus pneumonia. J Med Virol 28

81. Sharma KA, Kumari R, Kachhawa G, Chhabra A, Agarwal R, Sharma A, Bhatla N (2020) Management of the first patient with confirmed COVID-19 in pregnancy in India: from guidelines to frontlines. Int J Gynecol Obstet 23

82. Khan S, Peng L, Siddique R, Nabi G, Xue M, Liu J, Han G (2020) Impact of COVID-19 infection on pregnancy outcomes and the risk of maternal-to-neonatal intrapartum transmission of COVID-19 during natural birth. Infect Control Hosp Epidemiol 19:1-3

83. Khasawneh W, Khassawneh M, Zaghal LA, Hayajneh W, Abdelal F. The first Jordanian newborn delivered to COVID-19 infected mother with no evidence of vertical transmission: A case report

84. Lyra J, Valente R, Rosário M, Guimarães M (2020) Cesarean section in a pregnant woman with COVID-19: first case in Portugal. Acta Medica Port 20;33(13)
85. Kalafat E, Yaprak E, Cinar G, Varli B, Ozisik S, Uzun C, Azap A, Koc A (2020) Lung ultrasound and computed tomographic findings in pregnant woman with COVID-19. Ultrasound Obstet Gynecol 6

86. Xiong X, Wei H, Zhang Z, Chang J, Ma X, Gao X, Chen Q, Pang Q (2020) Vaginal delivery report of a healthy neonate born to a convalescent mother with COVID19. J Med Virol 10

87. National Registry for Surveillance and Epidemiology of Perinatal COVID-19 Infection: NPC-19 registry Info:https://collaborate.aap. org/SONPM/Pages/National-Perinatal-COVID19-Registry.aspx: updated on 15/05/2020

88. de Wit M, Peelen LM, van Wolfswinkel L, de Graaff JC (2018) The incidence of postoperative respiratory complications: a retrospective analysis of cuffed vs uncuffed tracheal tubes in children 0-7 years of age. Paediatr Anaesth 28(3):210-217. https://doi.org/10. 1111/pan. 13340

89. Thomas RE, Rao SC, Minutillo C, Hullett B, Bulsara MK (2018) Cuffed endotracheal tubes in infants less than $3 \mathrm{~kg}$ : a retrospective cohort study. Paediatr Anaesth 28(3):204-209. https://doi.org/10. 1111/pan.13311

90. Committee on Fetus and Newborn American Academy of Pediatrics (2014) Respiratory support in preterm infants at birth. Pediatrics 133(1):171-174

91. Bellini C (2020) COVID-19 outbreak impact on neonatal emergency transport. Pediatr Res 23. https://doi.org/10.1038/s41390-0201027-y

92. Cavicchiolo ME, Doglioni N, Ventola MA, Biban P, Baraldi E, Trevisanuto D (2020) Neonatal emergency transport system during COVID-19 pandemic in the Veneto region: proposal for standard operating procedures. Pediatr Res 7.

93. Bunyavanich S, Do A, Vicencio A (2020) Nasal gene expression of angiotensin-converting enzyme 2 in children and adults. JAMA 323(23):2427-2429. https://doi.org/10.1001/jama.2020.8707

94. Valiathan R, Ashman M, Asthana D (2016) Effects of ageing on the immune system: infants to elderly. Scand J Immunol 83(4):255266. https://doi.org/10.1111/sji.12413

95. De Luca D, Rava L, Nadel S et al (2020) The EPICENTRE (ESPNIC Covid pEdiatric neonatal registry) initiative: background and protocol for the international SARS-CoV-2 infections registry. Eur J Pediatr 179(8):1271-1278. https://doi.org/10.1007/s00431020-03690-9 